\title{
Contributing and constraining factors to collaborative land use planning: Consequences of proposed housing development "in and around" the New River Gorge National River
}

\author{
Candice Jo Ann Riley \\ West Virginia University
}

Follow this and additional works at: https://researchrepository.wvu.edu/etd

\section{Recommended Citation \\ Riley, Candice Jo Ann, "Contributing and constraining factors to collaborative land use planning: Consequences of proposed housing development "in and around" the New River Gorge National River" (2009). Graduate Theses, Dissertations, and Problem Reports. 2903.}

https://researchrepository.wvu.edu/etd/2903

This Thesis is protected by copyright and/or related rights. It has been brought to you by the The Research Repository @ WVU with permission from the rights-holder(s). You are free to use this Thesis in any way that is permitted by the copyright and related rights legislation that applies to your use. For other uses you must obtain permission from the rights-holder(s) directly, unless additional rights are indicated by a Creative Commons license in the record and/ or on the work itself. This Thesis has been accepted for inclusion in WVU Graduate Theses, Dissertations, and Problem Reports collection by an authorized administrator of The Research Repository @ WVU. For more information, please contact researchrepository@mail.wvu.edu. 


\title{
Contributing and Constraining Factors to Collaborative Land Use Planning: Consequences of Proposed
} Housing Development "In and Around" the New River Gorge National River

\author{
Candice Jo Ann Riley
}

Thesis submitted to the

Davis College of Agriculture, Forestry \& Consumer Sciences

At West Virginia University

In partial fulfillment of the requirements for the degree of

Master of Science

In

Recreation, Parks, and Tourism Resources

Steve Selin, Ph.D., Chair

Chad Pierskalla, Ph.D.

Peggy Pings, M.S.

Division of Forestry and Natural Resources

Morgantown, WV

2009

Keywords: Collaborative Land Use Planning, New River Gorge National River, Amenity Migration, National Parks 


\begin{abstract}
Contributing and Constraining Factors to Collaborative Land Use Planning: Consequences of Proposed Housing Developments "In and Around" the New River Gorge National River

Candice J. Riley

In recent years, population increases in gateway communities has led to developers wanting to development adjacent to public lands. Although gateway community developments provides economic benefits such as increases in jobs and tax revenues, the population increase can cause a negative change in the landscape of the public land. As a result, public land managers are approaching more collaborative ways to engage in land use planning.
\end{abstract}

The purpose of this study was to assess the level of support for collaborative land use planning in and around the New River Gorge National River in Fayetteville, WV, particularly focused on the context of rapid population growth in the Fayetteville area. This qualitative analysis used a triangulation method consisting of newspaper articles, documents, and 17 semi-structured interviews of individuals most directly involved in the New River Gorge housing development issue. From that information, we were able to identify an increased need to participate in collaborative land use planning both in the National Park Service (NPS) and stakeholders. We noticed several constraints to collaborative land use planning such as human and financial capacity and community resistance as well as how groups such as the Transition Team and the New River Working Group can better enhance collaborative land use planning efforts. Finally, we identified several keys to successful collaborative land use planning such as building relationships and better NPS engagement. For that reason, public land use managers and planners will be able to work with community members and with their help, make more effective policies and planning decisions. 


\section{Acknowledgements}

First I would like to thank my committee members; my committee chair, Dr. Steve Selin for all of your support and knowledge in helping me create this thesis topic, also for your encouraging words and guidance. I would also like to thank Dr. Chad Pierskalla and Peggy Pings for agreeing to be on my committee and for your additional support and guidance during this process as well. Next I would like to thank the National Park Service at the New River Gorge National River as well as the interview subjects for agreeing to participate in this study and providing us with a wealth of information to use in this study.

Last, but certainly not least, I would like to thank my friends and family for all of their love and support. To all my friends, thank you for your support and for allowing me you vent my frustrations to you guys. Finally my parents, Kenny Sr. and Greta, my sisters Keisha and Margaret, my brother Kenny, Jr. and my little nephew Kameron thank you for encouraging me to keep going an comforting me both on good days and on bad days. Without you this would not have been possible. I love my family! 


\section{Table of Contents}

Abstract

Acknowledgements

Table of Contents

List of Tables $\quad$ vii

List of Figures $\quad$ viii

Chapter I 1

$\begin{array}{ll}\text { Introduction } & 1\end{array}$

Purpose Statement 2

Research Questions 2

Assumptions

Limitations 3

Delimitations 3

Significance of Study 4

Chapter II 5

Literature Review $\quad 5$

Ecological and Social Change $\quad 5$

Rise of Collaborative Land Use Planning 9

Factors Constraining Collaborative Land 11

Use Planning

Facilitating Factors 14

Collaborative Land Use Planning Models 17

Keys to Successful Collaborative Land Use $\quad 18$

Planning

Chapter III 
Case Study Research

Participant Selection

Study Instruments

Data Analysis and Interpretation

Results

Case Study Timeline and Narrative

Statutory Support for Collaborative Land

Use Planning

Internal Collaborative Land Use Planning

Facilitators and Constraints

Internal Facilitators

Internal Constraints

External Collaborative Land Use Planning

Facilitators and Constraints

External Facilitators

External Constraints

Ongoing and Planned Collaborative Land

Use Planning Initiatives

Ongoing Initiatives

Potential Initiatives

Keys to Successful Collaborative Land Use

Planning 
Scientific Contributions to the Literature

Toward a Collaborative Land Use Planning

Framework

Suggestions for Future Research

Suggestions for Professional Practice

Appendices

Appendix A

Positions of Interview Participants

Appendix B 


\section{List of Tables}

Table 1. Case Study Timeline of Key Events and

Decisions

Table 2. Internal Factors to the National Park

Service

Table 3. External Factors Influencing Collaborative

34

Land Use Planning

Table 4. Collaborative Land Use Planning Initiatives

in the New River Gorge

Table 5. Keys to Successful Collaborative Land Use

Planning 


\section{List of Figures}

Figure 1. "In and Around" New River Gorge

National River

Figure 2. Contextual Factors Influencing Efficacy of

Collaborative Land Use Planning Efforts 


\section{Chapter I}

\section{Introduction}

In recent years, a growing number of people have been relocating from urban and suburban areas of the United States to smaller communities that border public lands for their scenic beauty and high quality of life (Howe, McMahon and Propst, 1997). This process, known as exurbanization (Carruthers and Vias, 2005), has contributed to population increases in these small gateway communities (Howe, McMahon and Propst, 1997). Gateway communities have "become a magnet for millions of Americans looking to escape the congestion, banality, and faster tempo of life in the suburbs and cities" (Howe, McMahon and Propst, 1997). Although exurbanization provides economic benefits to gateway communities by creating jobs and enhancing tax revenues, these population increases have negative consequences resulting from landscape change (Carruthers and Vias, 2005). For all these reasons, resource managers and community leaders are exploring more coordinated and collaborative approaches to land use planning at a landscape level.

Collaborative land use planning has many overlapping terms: coordinated planning, collaborative stewardship, collaborative planning, and coordinated resource management. For the purpose of this thesis we will use the term collaborative land use planning. Collaborative land use planning is a process in which stakeholders from different interests come together to discuss long term planning in a particular area usually with the use of a facilitator (Innes and Booher, 1999). Collaborative land use planning can be seen as both a way to deal with conflict when other strategies have failed and as a societal response to changing conditions where information is more widely distributed to networked societies (Innes and Booher, 1999). The National Park Service (NPS) has been engaged in a number of collaborative land use planning initiatives. As a result of the 1991 Vail, Colorado conference, NPS made collaborative land use planning their main priority through what is now known as the Vail 
Agenda (NPS, 2008, Selin and Chavez, 1995). Other initiatives include the National Recreation Strategy and the Rural Assistance Program (Selin and Chavez, 1995). Despite the interest in expanding collaborative land use planning, there is not much empirical work to guide policy and planning decisions.

\section{Purpose Statement}

The purpose of this thesis is to assess the level of interest and support for collaborative land use planning in and around New River Gorge National River in Fayetteville, WV, particularly focused on the context of rapid population growth and consequences of proposed housing developments in the Fayetteville area. The thesis will first assess what internal and external factors tend to facilitate or encourage participation in collaborative land use planning from the perspective of the National Park Service and key community planning partners. In addition, the thesis will analyze what internal and external factors tend to limit or constrain participation in coordinated planning as well as assess the potential to expand collaborative land use planning. Furthermore, the thesis will identify keys to successful collaborative land use planning so that resource managers and community leaders will be able to determine what is working in their collaborative land use planning efforts as well as what opportunities exist to expand collaborative land use planning.

\section{Research Questions}

RQ1: What internal factors tend to facilitate or encourage expanded participation in collaborative land use planning on the part of your agency?

RQ2: What internal factors tend to limit or constrain expanded participation in collaborative land use planning? 
RQ3: What external factors tend to facilitate or encourage expanded participation in collaborative land use planning on the part of your agency?

RQ4: What external factors tend to limit or constrain expanded participation in collaborative land use planning?

RQ5: What is the potential to expand collaborative land use planning? Can you identify specific ideas?

RQ6: What are some keys to successfully expanding collaborative land use planning?

\section{Assumptions}

1. Interviewees represented important planning partners to the NPS.

2. Our subjects' statements given during the interview accurately portray their perspectives on collaborative land use planning.

\section{Limitations}

This thesis is limited by:

1. The case study approach used for this thesis limits our ability to generalize the results to other resource and community systems.

2. The ability of the researcher to accurately interpret the validity of data.

\section{Delimitations}

The study is delimited to:

1. Those individuals who agreed to be interviewed. 
2. The sample selection consists of primarily Fayette County stakeholders

\section{Significance of Study}

Through collaborative land use planning, resource managers, community leaders, and planners can work together to tailor sustainable land use planning policy, reduce level of conflict, and reduce litigation. These people who work with resource managers and are affected by policy and planning decisions are known as stakeholders (Decker, Brown, and Siemer, 2001). Stakeholders are people who can have influence on a decision being made and some even have legal or political representation that can challenge a decision if needed (Decker, Brown, and Siemer, 2001).

There are some challenges to collaborative land use planning beginning with identifying who the stakeholders are (Decker, Brown, and Siemer, 2001). The stakeholders can range from someone who lives near the gateway community to someone who lives miles away, but visits the area on a regular basis. Another challenge is determining the impact the decisions have on future generations (Decker, Bown and Siemer, 2001). Despite these challenges, collaborative land use planning is important in sustainable community planning because it can help community members work with resource managers to "accomplish collective and organizational goals" (Selin and Chavez, 1995). Research can provide city and county officials, public land use managers and planners with usable knowledge to allow them to work with community members to forge more effective policies and planning decisions. 
Chapter II

\section{Literature Review}

\section{Ecological and Social Change}

Collaborative land use planning is gaining acceptance as a result of rapid ecological and social change occurring in gateway communities. Ecological change is occurring as a result of population increases in gateway communities. For example, the increased use of natural amenities by gateway community residents and visitors does not always support sustainable development (Glorioso and Moss, 2007). An increase in gateway community development comes at the expense of natural open space (Carruthers and Vias, 2005), that "alters the landscape directly through habitat destruction, modification and fragmentation all of which alter landscape functioning" (Theobald, Gosnell and Riesbsame, 1996). Ecological change in gateway communities can also cause increased soil, water, air, and noise pollution (Glorioso and Moss, 2007) and increased human/wildlife interaction and pet/wildlife interactions (Stewart, 2000) as well as the spread of exotic species (Theobald, Gosnell, and Riebsame, 1996). Endangered species such as the pronghorn antelope in Yellowstone National Park are having their habitat continually encroached by gateway community development causing loss of refuge from predators such as coyotes (Hansen et al, 2002). Ecological changes of gateway communities also lead to a demand for better infrastructure (Davis and Nelson, 1994). As population increases the infrastructure becomes overwhelmed and limited. Most gateway communities' infrastructure is either outdated or old and the town government cannot afford to upgrade or replace their infrastructure (Stewart, 2000). Building, expanding, or upgrading roads is also expensive and has its own ecological impacts, but must be accomplished to accommodate the increased population (Stewart, 2000). 
Rapid social change is occurring in gateway communities as well. Gateway communities provide residents with better access to outdoor recreation opportunities (Davis and Nelson, 1994). According to a 1995 survey of Columbia River Basin residents, outdoor recreation is the second most important reason exurban residents' move to a gateway community (Rudzitis, 1999). Exurban residents tend to be more environmentally conscious (Davis and Nelson, 1994) and the quality of the environment is an important reason why they move to the area (Rudzitis, 1999). In addition to the close proximity of outdoor recreation opportunities, gateway communities have lower land and housing prices because they are considered rural communities (Carruthers and Vias, 2005).

Another aspect of social change in gateway communities is the economic development that occurs as a result of new exurban residents. An example of the economic development would be an increase in jobs and more dollars coming into the community. Construction workers are needed to build residential developments along with roads and other infrastructure. Construction is not the only trade benefiting from gateway community development. Corporations such as Sony are expanding into gateway community areas as a way to attract current and new exurban residents as well as invite people to the area. The Sony Corporation opened a new compact disc factory in Springfield, Oregon, located along the Willamette River Valley that provides 1,500 jobs (Eagn, 1994). Small businesses are relocating as well. For instance, Nancy McMorrow relocated her family's plastic manufacturing business from Long Island, New York to Belgrade, Montana after being in New York since 1956 (Snepenger, Johnson, and Rasker, 1994). Belgrade, Montana is a community that sits along the northern edge of the Yellowstone Ecosystem (Howe, McMahon, and Propst, 1997). McMorrow's plastic manufacturing business brought 24 jobs to Belgrade (Snepenger, Johnson, and Rasker, 1994). With the jobs that exurban residents bring into the area, those jobs will allow more money to be spent in the community's restaurants and shops allowing economic prosperity to a community that could have at one point, struggled to make ends 
meet. Most gateway communities also double as tourist areas for events such as bird watching. Harligen, Texas, a community outside of Laguna Atascosa National Wildlife Refuge hosts an annual birding gala that in 1995 drew 1,800 people and brought 1.6 million dollars into Harligen's local economy (Howe, McMahon, and Propst, 1997).

In addition to economic development in, social capital is an aspect of social change in gateway communities as well. Social capital refers "to features of social organization, such as networks, norms, and trust, that facilitate coordination and cooperation fro mutual benefit" (Flora et al, 1997). When exurban residents move to an area, they can bring with them new skills and capacity that can aid in economic development and sustainability of the community (Putnam, 1993). The new capacity and cooperative action among new residents and original community members is called entrepreneurial social infrastructure (ESI) (Flora et al, 1997). ESI is a "format for converting social capital into organizational forms that facilitate collective action" (Flora et al, 1997). It is understood that communities that utilize ESI tend to be more successful at executing economic development practices than communities who do not utilize ESI (Flora et al, 1997). For example, a study of rural communities conducted by Flora et al (1997) discovered that communities with high ESI levels mobilized resources to strengthen environmental capital, established community wide recycling programs, created green space, and were finding alternatives to polluting industries. Consequently, the community becomes diversified as a result of exurban residents allowing these rural communities initiatives to be possible (Granovetter, 1985).

Finally, social change in gateway communities occurs because of the better quality of life residents experience in gateway communities. Exurban residents feel that gateway communities are a better place to raise a family (Davis and Nelson, 1994) as well as having lower levels of crime, pollution, noise, and congestion (Davis and Nelson, 1994). According to a 1995 survey of Columbia River Basin 
residents, 70 to 80 percent of exurban residents surveyed agreed that their new locations were "less stressful, more enjoyable, happier, and healthier" (Rudzitis, 1999). Some exurban residents even sacrifice shorter commutes to work in urban or suburban areas for longer commutes to in order to maintain their quality of life in their gateway community. A survey respondent in a case study of exurban areas of Portland, Oregon stated: "The quality of life in our rural setting (lower crime rate, privacy, clean air, and quiet) is worth the additional commute time" (Davis and Nelson, 1994). Another respondent added, "You couldn't pay me to live where I work [in Portland]!" (Davis and Nelson, 1994).

However, the increase in population in gateway communities can lead to a perceived loss of small town appeal (Stewart, 2000). Some locals may see their community as being dramatically changed to "appeal to amenity migrants' and tourists' image of an idyllic Alpine village which frequently results in a cultural and physical Disneyland (Glorioso and Moss, 2007). That change is then accompanied by a real or perceived loss of local control that starts with the reduced ability of long term residents to live within their community due to increased taxes, rent, property commercial values and ownership by outsiders (Glorioso and Moss, 2007). As the cost of living increases, long term residents tend to segregate themselves from the new exurban residents eventually leading to tension and conflict (Glorioso and Moss, 2007). Even though some residents might welcome the new ideas exurban residents have for their new community, there still can be a difference of opinion among old residents and new exurban residents. There can even be a difference of opinion among old residents and new exurban residents. There can even be a difference of opinion between exurban residents and resource managers (Stewart, 2000). Practices that were once standard for resource managers might be called into question by new exurban residents (Stewart, 2000). For instance, resource managers might adopt natural fire policies that would allow some fires to just burn themselves out (Riebsame, Gosnell, and Theobald, 1996). As development increases on public land borders, exurban residents would see this 
practice as unacceptable and would push for policies on adjacent lands that protect and enhance their own land values.

As population growth measures increase and impacts mount, there has been a growing trend toward regional and landscape level approaches to natural resource planning and management. Resource managers and community leaders are increasingly calling for more coordinated and collaborative approaches to land use planning. Resource managers and community leaders are beginning to work together to develop initiatives to solve problems and build a sustainable future in their community (Wondolleck and Yaffee, 2000). In addition to the ecological and social change mentioned earlier, it is important to understand other societal forces leading to collaborative land use planning responses. For example, what caused the trend toward collaborative land use planning in the first place, to factors constraining, facilitating, and designing collaborative land use planning as well as keys to successful collaborative land use planning.

\section{Rise of Collaborative Land Use Planning}

As stated earlier, collaborative land use planning is a process in which different stakeholders with different interests come together to discuss long term planning with the use of a facilitator (Innes and Booher, 1999). Previous literature lists several overlapping terms in regard to collaborative land use planning: collaborative stewardship, coordinated resource management, and collaborative planning. Each term is similar in its definition of "diverse stakeholders [working] together to address natural resource management issues" (Coughlin et al, 1999). Collaborative land use planning has become popular among land managers in recent years because of the growing communities resulting in differences in knowledge and values among individuals (Innes and Booher, 1999). If land managers want to achieve successful land management planning, it is going to require "creating flexible linkages among 
many players" (Innes and Booher, 1999). Collaborative land use planning can be seen as both a way to deal with conflict when other strategies have failed and as a societal response to changing conditions where information is more widely distributed to networked societies (Innes and Booher, 1999). Other potential benefits of collaborative land use planning include increased management effectiveness, greater suitability of management actions, increased trust between stakeholders and government agencies, reduced enforcement expenditures and increased public awareness of conservation issues (Schusler et al, 2003).

One of the most well known collaborative land use planning examples is in Jackson Hole, Wyoming. Located along the borders of Yellowstone and Grand Teton National Parks as well as the National Elk Refuge, the population of Jackson Hole doubled in the 1970s and by 1980, grew by more than 25 percent (Howe, McMahon, Propst, 1997). The increase in the population was caused by visitors who liked the area so much they moved to Jackson Hole permanently or built a second home (Howe, McMahon, Propst, 1997). Soon after, outlet stores emerged, wildlife habitat was threatened, and housing prices skyrocketed (Howe, McMahon, Propst, 1997). In 1995, Teton County and Jackson Hole both adopted a new land-use plan which grew as a result of a public workshop attended by more than 300 residents (Howe, McMahon, Propst, 1997). The plan includes financial incentives for landowners who conserve their properties, viewshed guidelines for developers, and affordable housing for residents (Howe, McMahon, Propst, 1997). Even though some residents either wish the plan was more aggressive or less aggressive, they all agree that the plan is an important step in protecting Jackson Hole's resources (Howe, McMahon, Propst, 1997). Although the Jackson Hole, Wyoming example illustrates the factors that help make collaborative land use planning a beneficial tool in natural resource management, there are factors that constrain collaborative land use planning as well. 


\section{Factors Constraining Collaborative Land Use Planning}

Previous literature lists several factors constraining collaborative land use planning. First, Selin and Chavez (1995) list institutional and situational factors that constrain collaborative land use planning. Common constraints of collaborative land use planning within many agencies are the institutional culture and lack of flexibility (Selin and Chavez, 1995). The intuitional culture constraint is that many agencies use a "centralized rational-comprehensive planning process" when it comes to collaborative land use planning meaning the agencies try to form collaborative plans based on the agency as a whole and not necessarily based on the needs of other involved parties (Selin and Chavez, 1995) The lack of flexibility in collaborative land use planning consists of agencies not being flexible in regards to procedures for implementation of agreements and processing financial resources (Selin and Chavez, 1995).

There are institutional factors constraining collaborative land use planning in environmental groups as well (Schatz et al, 1991). Many environmental groups think collaborative land use planning waters down their mission, and feel obligated to their group members to set distinct environmental objectives and pursue those objectives with as much energy as possible (Hayes, 1988). Most environmental groups are not afraid to use litigation to pursue their objectives because litigation gives environmental organizations a visible forum to express their views unlike a collaborative land use planning session that is handled more conservatively (Selin and Chavez, 1995).

Other factors constraining collaborative land use planning is the relationship between different stakeholders. Organizations that have been bitter rivals in the past will not be able to reach an agreement on anything (Selin and Chavez, 1995). For instance, some traditional public involvement methods used by the USDA Forest Service "actually deepened the chasm between traditional 
adversaries by encouraging them to protect their own interest and find other avenues through which to influence the final outcome" (Seln and Chavez, 1995). Differences in power are another factor constraining collaborative land use planning such as stakeholder groups with a perceived amount of power as well as groups with a perceived lack of power (Selin and Chavez, 1995). The forest service, again for example, have been criticized on making decisions that they determined would best suit the public without involving the public in their decision making process (Selin and Chavez, 1995).

Finally, there are some factors constraining collaborative land use planning at which point collaborative land use planning is no longer feasible (Gray, 1989). Some examples include, unsuccessful attempts at collaborative land use planning the past, being unable to use or locate a facilitator, the issue is "rooted in basic ideological differences" or "constitution issues are at stake or legal precedents are sought" (Selin and Chavez, 1995).

The barriers or constraints noted by Wondolleck and Yaffee (2000) include institutional and structural barriers, barriers due to attitudes and perceptions, and with the process of collaboration. The institutional and structural constraints are similar to those noted earlier by Selin and Chavez (1995). First, there is a lack of opportunity or incentives at which few opportunities for collaboration are available and "the incentives perceived by the stakeholders push them away from working together" ( $p$. 51). Secondly, the conflicting goals and missions of stakeholders constrain the collaborative land use planning (p.52). For example, there may be a stakeholder group whose mission is to supply "drinking and irrigation water and flood control to the public" and another stakeholder's mission might be to "ensure water quality and wetlands protection" (p.52). Inflexible policies and procedures and existing rules and regulations are constraints as well. For instance "red tape and burdensome procedures" as well as "existing jurisdictions and institutions" can frustrate stakeholders therefore greatly affecting the 
collaborative land use planning process (p. 53; Koontz, 2003). Constrained resources such as a lack of time, money, or personnel are also a factor constraining collaborative land use planning (p. 57).

Barriers due to attitudes and perceptions include mistrust between stakeholder groups usually due to past interactions or stereotypes of the different groups (p.58). Also, how each stakeholder group perceives each other can be a factor constraining collaborative land use planning as well (p. 58). An example of this would be community residents attitudes toward federal agencies such as the NPS or Forest Service that they are not to be trusted (p. 58). Other attitudinal and perception constraints include organizational norms and culture in which collaborative land use planning goes against traditional management techniques, and a lack of support from land managers for collaborative land use planning (p. 62).

Problems with the collaboration process itself can constrain collaborative land use planning ( $p$. 63). Potential stakeholders could be unfamiliar with the collaborative land use process, lack the skills necessary for the collaborative land use planning process, and when stakeholders are involved in conflicts outside of the collaborative land use planning process (p.64).

Lastly, Koontz, (2003) adds that the current use of the land can be a constraining factor to collaborative land use planning as well. Stakeholders who live in areas that have seen "rapid conversion of ...open space to development" will view problems and solutions differently than those stakeholders who live in areas where open space has not been developed (Koontz, 2003). Although there are several factors that can constrain collaborative land use planning, there are factors that can make collaborative land use planning easier. 


\section{Facilitating Factors}

As stated earlier, collaborative land use planning has become a more common way land resource managers and stakeholders work together to deal with land use planning and policy issues (Innes and Booher, 1999; Schusler et al, 2003). In addition to collaborative land use planning "focusing on the problem in new and different ways" Wondolleck and Yaffee, (2000), lists six other factors that facilitate collaborative land use planning. The first factor is the willingness to try new approaches (p.121). Stakeholders must be willing to interact differently than they are used to (p.122). Stakeholders also need to "establish a non-combative approach to discussions" as well as be "flexible in considering solutions to problems" in order to be successful in collaborative land use planning (p.123).

The second facilitating factor is a holistic perspective. A holistic perspective is the ability to take a different approach to a problem and focusing on the problem as a whole (Grumbine, 1994). This can be achieved by integration geographically, functionally, and different elements of a problem (Wondolleck and Yaffee, 2000). An example of geographic integration according to Wondolleck and Yaffee (2000) is combining agencies together to form one agency that works together to look at an issue and come up with strategies to solve the issue (p.125). An example of functional integration is to work with stakeholder groups simultaneously instead of separately (p.126). Integrating different elements of a problem includes "expanding the focus from one set of objectives to a broader set most typically to include both environmental and economic aspects of a situation" (p.126).

The third facilitating factor is focusing on the problem and not constraining it to the positions of the group as well as organizational procedures (Gray, 1989). This can be achieved by appropriately defining the problem to be solved, focusing on the stakeholders' interest and not their positions, and not allowing "preexisting agency norms and procedures to preclude or limit their efforts" (Wondolleck 
and Yaffee, 2000). The fourth facilitating factor is that collaborative land use planning should not be limited to traditional conceptions of agency roles (p.130). Agency officials such as the National Parks Service or USDA Forest Service have historically viewed their role in communities as experts with a "we know best" perspective (p.130). Instead, agency officials should be available to provide expertise but not in a overbearing manner that may hinder the collaborative process (p.131).

The fifth facilitating factor is a willingness to learn together. Participants of the collaborative land use planning process have to agree that "they individually do not have all the answers", but by sharing information, developing options, and taking time to develop an understanding of the process, they can together agree on a plan (Wondolleck and Yaffee, 2000). An example of sharing information is agency officials such as the USDA Forest Service sharing research and management information with their stakeholders (p.132). In developing options, collaborative land use participants can brainstorm solutions to a plan in which all participants sit down together and write down as many ideas they can to solve a particular issue (Fisher, Ury, and Patton, 1991). In taking the time to develop understanding, collaborative land use planning participants can ensure that everyone involved has an understanding of the information by taking the time to explain any data or jargon that might confuse any of the stakeholder groups (Fisher, Ury, and Patton, 1991).

The last facilitating factor in collaborative land use planning is to use scientific information as a way to connect to the current problem. Scientific information is a way to prove a decision is justified (Wondolleck and Yaffee, 2000). Also, using an independent scientific expert allows for the information gathered to not be biased and answers the questions honestly and not emotionally (p.134). Collaborative land use planning participants can also use an adaptive management approach whenever scientific information is uncertain (p.136). An example of adaptive management is using pilot projects or demonstration projects (p.136). These projects occur for a certain period of time and once the 
project ends, collaborative land use planning participants can evaluate the project and respond to the project based on the information gained and decide whether to continue the project or terminate it (p.137).

In their book, Human Dimensions of Wildlife in North America, Decker, Brown, and Siemer (2001) explain several approaches to stakeholder involvement. There is the expert authority approach that can be applied where there are few stakeholder groups involved "and the stakeholders recognize that the experts share their values" (p.135). The passive-receptive approach can be used when managers welcome stakeholder input but do not "seek it systematically" (p.136). The inquisitive approach is when managers actively seek out stakeholder input in an effect to understand stakeholder positions regarding a specific issue or "before an anticipated problem becomes a public issue" (p.137). The transactional approach is when managers understand that "weighting different stakeholders' stakes will play a major role in management decisions" (p.139). Finally, the comanagerial approach occurs when problems continue, "greater public expectations for solutions tailored for their communities, increasing responsibilities for agencies, and continuing limitations on agency funds and personnel" (p.142). Another facilitating factor in collaborative land use planning is social learning (Schusler et al, 2003). Social learning occurs "when people engage one another, sharing diverse perspective and experiences to develop a common framework of understanding and basis for joint action" (Schusler et al, 2003). In the case of collaborative land use planning, stakeholders come together sharing their different views on an issue in hopes of developing a policy that everyone can agree on (Schusler et al, 2003). There are many facilitating factors in collaborative land use planning. Although these factors make collaborative land use planning possible it is also important to examine how others have designed collaborative land use planning as well. 


\section{Collaborative Land Use Planning Models}

A number of collaborative land use planning models have been advanced in the scientific literature. Some of these models include tourism partnerships (Selin and Chavez, 1995), adaptive management (Allan and Curtis, 2003), and search conferences (Selin et al, 2007). The evolutionary model of tourism partnerships, or in this case, of collaborative land use planning consists of five steps: antecedents, problem-setting, direction-setting, structuring and outcomes" (Selin and Chavez, 1995). The antecedents step consists of basically looking at what events transpired to cause the issue and what existing networks are available (Selin and Chavez, 1995). In the problem-setting step, planners look at the problem, try to seek consensus on legitimate stakeholders, as well as the perceived significance to stakeholders (Selin and Chavez, 1995). For direction-setting, planners establish the goals of the planning process, set some ground rules, explore options, and divide the stakeholders into sub-groups (Selin and Chavez, 1995). The structuring step consists of assigning roles elaborating the tasks assigned and monitoring and controlling the systems, designed (Selin and Chavez, 1995). Finally in the outcomes step, programs are established, impacts are assessed, and the benefits of the program are examined (Selin and Chavez, 1995).

Adaptive management in collaborative land use management "involves learning from management actions and using that learning to improve the next stage of management" (Allan and Curtis, 2003). Adaptive management in collaborative land use planning allows resource managers to 1) "proceed in the face of complexity and uncertainty; 2) make learning about natural resource systems more efficient; 3 ) help build flexible management capacity; 4) be a large scale holistic alternative to reductionist science; and 5) involve social and political values in ecosystem management" (Allan and Curtis, 2003). Adaptive management consists of several steps; fostering support, identifying stakeholders, constructing a conceptual model, develop objectives, identify key uncertainties, create 
management options, implement the management options, and monitor, evaluate and reflect the options (Allan and Curtis, 2003). The process can be repeated for as long as it is necessary (Allan and Curtis, 2003).

Finally, collaborative land use planning can be designed using a search conference (Selin et al, 2007). A search conference is "a participatory event that enables a large group to collectively create a plan that its members themselves will implement" (Selin et al, 2007). A search conference usually lasts between 2-3 days and starts by first conducting a wide environmental sign, then narrows down to specific goals, visions, and themes for the present management system (Selin et al, 2007). Finally, the search committee group develops an action plan and assigns responsibilities to ensure the plan gets implemented (Selin et al, 2007). By examining ways in which others have designed collaborative land use planning, we can now determine some keys to successful collaborative land use planning suggested in previous literature.

Keys to Successful Collaborative Land Use Planning

Selin and Schuett (2002) lists six keys to successful collaborative land use planning: Development, information exchange, organizational support, interpersonal communication, relationships/team building, and accomplishments. In development, it is important to have "a specific purpose, goals, and representation from all affected parties" (p.158), meaning you have to be able to know the reason collaborative land use planning is needed and ensure that key stakeholders were involved. The second category, information exchange explains the importance of exchanging information so that all party members including key stakeholders and community members are informed in regards to research and progress updates pertinent to the collaborative land use planning process (p.158). 
The third category or key to successful collaborative land use planning is organizational support (Waddock and Bannister, 1991). Organizational support included "regularly scheduled meetings, funding, staff, and necessary resources" (Selin and Schuett, 2002). Organizational support is not only needed internally within a specific organization or group, but externally as well from surrounding communities (p.158). The fourth key to successful collaborative land use planning is interpersonal communication (Gray, 1985). Communication includes "listening, understanding, discussing and decision-making" (Selin and Schuett, 2002). The fifth key to successful collaborative land use planning involves establishing relationships and team building (p.158). It is necessary for all key participants to be able to establish a level of trust and build relationships with each other (p.158). Participants should also be honest and forthcoming with all stakeholders involved in the collaborative land use planning process. Finally, the sixth key to successful collaborative land use planning deals with accomplishments (p.158). There has to be some sort of achievement or accomplishment in the collaborative land use planning process (p.158). The accomplishment can happen through an action being taken on a particular initiative, a final report drafted on an initiative or even evaluating the collaborative land use planning process itself to see if the process did or did not work and if collaborative land use planning would be useful in the future (p.158).

Frame, Gunton, and Day (2004) list other keys for a successful collaborative land use planning process. They determined that an effective process management, a clearly defined purpose and objectives, inclusive representation of all relevant interests, access to highly quality information much like Selin and Schuett's (2002) information exchange are very important keys to successful collaborative land use planning process (Frame, Gunton, and Day, 2004). Other very important keys include mutual respect and trust in negotiation, clear rules of the procedure, participants having a clear understanding of their own and other's interests, accountability and openness of the process to the public, 
commitment to plan for implementation and monitoring and commitment of stakeholders to the process (Frame, Gunton, and Day, 2004). The authors note other important keys to successful collaborative land use planning. Those important keys are accountability of representatives to their constituencies, process design that is flexible and adaptive, clearly defined consequences and an alternative if a consensus is not reached, and participants having equal opportunity (Frame, Gunton, and Day, 2004). In addition to the above mentioned keys to success, participants having equal resources, using an independent facilitator having a clear timetable including a deadline for reaching an agreement, consensus requirement, voluntary participation, urgent and significant issues, and a process designed by participants but with use of a clear framework are also other important keys to successful collaborative land use planning.

Finally, Wondolleck and Yaffee (2000) explain that the recipe for successful resource management consist of: 1) getting good quality information; 2) obtain capable people from a spectrum of interests at an appropriate geographic scale; 3) Provide those people with opportunities for interaction and exploration and give incentives for finding creative solutions to problems: 4) Enable them to implement solutions in a way that would mobilize resources, shares ownership, and move toward a future that will be characterized by the changes in values and knowledge; and 5) mix thoroughly, provide resources and stand out of the way (Wondolleck and Yaffee, 2000). For that reason, public land managers can use the successful keys to collaborative land use planning as a means to better engage stakeholders in land use decisions(Wondolleck and Yaffee, 2000). 


\section{Chapter III}

\section{Methodology}

\section{Case Study Research}

Case study research "is used in many situations to contribute to our knowledge of individual, group, organizational, social, political, and related phenomena" (Yin, 2003). Case study research allows researchers to "retain the holistic and meaningful characteristics of real life events" and study the events as they are happening (Yin, 2003). In his book, Case Study Research: Design and Methods, Robert Yin (2003) also defines case study research as an inquiry that investigates a "phenomenon within its real life context, especially when the boundaries between phenomenon and context are not clearly evident." In the case of our thesis, since the phenomenon of collaborative land use planning in gateway communities is not evident and a relatively new concept, case study research is an appropriate methodology. Additionally, case study research "relies on multiple sources of evidence with data needing to converge in a triangulating fashion" (Yin, 2003). Triangulation is needed when handling multiple sources of data to control for possible biases caused by the researcher (Selin and Chavez, 1995). The multiple sources of evidence for this thesis includes semi-structured interviews with key stakeholders, newspaper articles, websites, planning and legislative documents.

\section{Participant Selection}

The participant selection process consisted of locating individuals who were "the most directly involved and knowledgeable" (Selin and Chavez, 1995) regarding the New River Gorge housing development. Our first interview participants were NPS employees. From that interview we gathered additional key participants using a snowball sampling method (Patton, 2002) until we reached a saturation point in which names were repeatedly mentioned (Patton, 2002). A total of 17 interviews 
were conducted with respondents ranging from NPS personnel from the New River Gorge National River, city and county officials from Fayetteville and Fayette County, local business owners, environmental advocacy group members, to residential developers planning to build along the gorge rim (see Appendix A). The semi-structured interviews were conducted during spring and summer 2008 and lasted between 30 minutes to one hour. Of the 17 interview participants, only one refused to be tape recorded at which point vigorous notes were taken. The tape recorded interviews were then transcribed verbatim for analysis (Selin and Chavez, 1995). The key stakeholders were interviewed about efforts made toward collaborative land use planning, specific initiatives for collaborative land use planning, constraints to collaborative land use planning, and keys to successful collaborative land use planning.

Study Instruments

The study instrument used in this thesis is an interview questionnaire (see Appendix B). The interview consisted of seven questions not including one question asked only to government agencies. The design of the interview was all premised on collaborative land use planning within the context of proposed and planned housing development. The questionnaire first started with the interviewer explaining the reason for the study and who they hoped to interview for the study. Next, the interviewer asked the respondent if he or she agreed to be recorded for accuracy ensuring that they would remain anonymous. The interviewer then asked the respondent to state their job title. The question asked for governmental agencies was to identify what support was available in their organization whether that support was statutory or administrative, to engage in regional planning efforts outside the agencies' jurisdictional boundaries. The next question, respondents were asked to name some factors that would encourage their organization to engage in regional coordinated planning in the case of the New River Gorge National River. Conversely, respondents were asked to describe 
factors that would constrain or limit their organization's participation in collaborative land use planning. In the next interview question, respondents were asked to name some specific projects where their organization engaged in collaborative planning in the New River Gorge region over the past six years. Following that question, respondents were asked to list any specific ideas for the potential for expanding the scope of collaborative planning efforts. The next question asked was to identify some keys to successfully expanding the scope of regional coordinated planning efforts in the New River Gorge National River. In contrast, respondents were asked to name some constraints to expanding the scope of regional coordinated planning efforts. The final question the interviewer asked respondents were to name other people we should speak with in conducting the study. Again as stated earlier, a total of 17 respondents were interviewed with the interviews lasting between 30 minutes to one hour.

\section{Data Analysis and Interpretation}

Qualitative research methods are used in this study because qualitative research methods "facilitate study of issues in depth and detail" (Patton, 2002). With qualitative research you can obtain a wealth of detailed information from only a small number of people (Patton, 2002). As opposed to quantitative research that relies mostly on statistical data, qualitative research allows you to rely on multiple sources of information such as written documents and observations. Patton (2002) notes that there are three kinds of qualitative data: interviews, observations, and documents. Interviews are “open-ended questions and probes yield in-depth responses about people's experiences, perceptions, opinions, feelings and knowledge. Data consist of verbatim questions with sufficient context to be interpretable" (Patton, 2002). Observations are basically fieldwork descriptions of behaviors, mannerisms, actions, and interactions of a subject (Patton, 2002). The researcher makes field notes to be used in the data analysis (Patton, 2002). Documents are any written materials such as official publications, letters, and reports that the researcher can obtain excerpts from as long as the documents 
are "captured in a way that records and preserves context" (Patton, 2002). For my study I will be relying on interviews conducted of officials from Fayetteville and Fayette County, National Parks Service (NPS) employees, and residential developers. I will also use documents consisting of newspaper articles on residential development along the New River Gorge from various local and regional newspapers.

To analyze the data in order to address our research questions we will use content analysis and open coding. Content analysis is referred to as "searching text for recurring words or themes" (Patton, 2002). Conducting a qualitative content analysis is simply creating an interpretation of a text and supporting the interpretation of a text and supporting the understanding with quotes from the text being analyzed and forming conclusions and parallelisms based on the interpretations (Krippendorff, 2004). For our study we will scan the information obtained from the interviews, meeting minutes, and newspaper articles to examine the trend of collaborative land use planning in the New River Gorge National River. From the themes we gather from the data we can use open coding. As Patton (2002) states, coding means to analyze the content of the data to determine what is significant. I will read through the data and develop codes for each recurring theme mentioned in the data.

To analyze the themes into which the information gathered belongs to as well as categories that could help explain the trend toward collaborative land use planning in the New River Gorge National River, I will use a software program called NVIVO. NVIVO will help sort the date more accurately into recurring themes. I can upload all the collected data (i.e. newspaper articles, interview transcripts, meeting minutes) into the program and NVIVO will analyze the data once I type in the themes to look for. After the themes are sorted and organized, I will develop categories in which the information collected falls into. 


\section{Chapter IV}

\section{Results}

Case Study Timeline and Narrative

A case study timeline (Table 1) was developed to provide a historical and economic context for the meanings imbedded in participant interviews conducted as part of this research study. The timeline focuses particularly on land use planning events which have occurred at both the Fayette County and National Park Service unit levels. The timeline is also pinned to economic events at a national level to illustrate connections between the national economic climate and unfolding events in Fayette County. The following section provides a detailed narrative of the events surrounding the New River Gorge National River housing development issue.

Residential development adjacent to the New River Gorge was first proposed in January 2004. One year later, Atlanta Based Land Resources Companies made plans to develop 4,300 acres of land adjacent to the New River Gorge into residential developments named Roaring River. Soon after, a second developer, New River Ledges Associates began making plans to develop 1,400 acres of land along the New River Gorge naming those developments, BridgeView Estates. These large scale housing proposals led to significant public concern over potential social and ecological impacts in the New River Gorge National River. As a result, Fayette County held two public meetings in August and September 2005 to seek public input about whether to reclassify the land adjacent to the New River Gorge for development. The land was to go from being classified as R-R (Rural Residence District) and LC-1 (Public Land Conservation District) to R-R with PRD (Planned Residential District). The meetings were attended by developers, environmental groups as well as concerned citizens speaking either for or against 
proposed development. Speakers also included NPS employees who gave a presentation on where these developments were in relation to the park and how visible they would be from the gorge.

In January 2006, the Fayette County Planning Commission approves LRC's plan for development, reclassifying the land as R-R with PRD so that they could begin building. That same month, NPS began informational meetings and public input meetings about the park's General Management Plan (GMP) to discuss the "future integrity of the New River Gorge National River Park." Months later in May 2006, four conservation groups: Plateau Action Network (PAN), National Parks Conservation Association (NPCA), West Virginia Highlands Conservancy, and National Committee for New River file an appeal of the Fayette County Planning Commission's decision to rezone and allow for LRC's proposed plan for development to occur. By filing an appeal, the groups hoped to protect New River Gorge's viewshed and the park's scenic beauty. While the appeal for LRC's plan for development was being appealed, the Fayette County Planning Commission went on to approve BridgeView Estates plan to build on 1,400 acres adjacent to the gorge rim. In September 2006, the Board of Zoning Appeals (BZA) votes unanimously to uphold the approval of LRC's Roaring River housing development again allowing LRC to continue the plan for development. In that same month, NPS superintendent Cal Hite announced his retirement at the end of the year. The next month, October 2006, conservation groups PAN and NPCA file a second appeal against the New River Gorge housing development but soon dropped the appeal a month later after the County Commission unanimously approved a resolution that addressed the groups' concerns toward current and future development along the New River Gorge.

In 2007 design and initial construction began at New River Gorge. In April, Don Striker was hired as the new NPS superintendent. In addition to Roaring River and BridgeView Estates, Fayette County Planning Commission approved a 744 housing development called Wild Rock West Virginia that surrounds the headquarters of Class VI River Runners. In January 2008, NPS began working on a draft 
for the New River Gorge's General Management Plan. The following month, signs of the impending economic downturn became apparent with then President George W. Bush signed an economic stimulus package, allowing money to be disbursed to tax payers as a means to help stimulate the economy. A few months later in May 2008, when many of the interviews were conducted for this research study, Fayette County held a stakeholder meeting for a proposed viewshed ordinance which was attended by various stakeholders; developers, environmental groups, NPS personnel, residents and other interested parties. The goal of the stakeholder meeting was to engage the public in collaboratively developing a viewshed ordinance for the New River Gorge Region.

Signs of the economic downturn became even more apparent in July 2008 when LRC closed their Fayetteville office laying off all of their employees and construction on Roaring River was stopped. The economic downturn affected BridgeView Estates as well, with the development in negotiations with NPS to sell 100 acres of land to NPS with the hopes of buying up to 500 acres if the deal goes through in August. Two months later, in October 2008, LRC file for bankruptcy, putting the current land already in development along their Roaring River property in further jeopardy. Then, in December 2008, LRC'S 4,300 acres were sold at auction. In 2009, President Barack Obama was inaugurated in January and in February, he signed another economic stimulus package in one more attempt at getting the economy back on track. This time, President Obama provided funds to businesses in hopes of creating jobs and improving the country's infrastructure. As of March 2009, the GMP for the New River Gorge was under internal NPS review and is expected to be released in final form later this year. 
Table 1. Case Study Timeline of Key Events and Decisions surrounding the New River Gorge National River Housing Developments

\begin{tabular}{|c|c|}
\hline Date & Key Events/Decisions \\
\hline January, 2004 & Residential development in the NRG was first proposed \\
\hline January, 2005 & $\begin{array}{l}\text { Land Resources Company (LRC) plans to build 2,200 } \\
\text { homes on 4,300 acres along NRG called Roaring River }\end{array}$ \\
\hline July, 2005 & $\begin{array}{l}\text { New River Ledges Associates plans to build 1,400 acres } \\
\text { along the NRG called BridgeView Estates }\end{array}$ \\
\hline August 26 and September 26, 2005 & $\begin{array}{l}\text { Public meetings held concerning land reclassification for } \\
\text { development }\end{array}$ \\
\hline January, 2006 & $\begin{array}{l}\text { Fayette County Planning Commission approves LRC's } \\
\text { plan for development }\end{array}$ \\
\hline January, 2006 & $\begin{array}{l}\text { NRG begins having public input meetings for the } \\
\text { General Management Plan (GMP) for the next two } \\
\text { years }\end{array}$ \\
\hline May, 2006 & $\begin{array}{l}\text { Conservation groups Plateau Action Network (PAN), } \\
\text { National Parks Conservation Association (NPCA), West } \\
\text { Virginia Highlands Conservancy (WVHC), and the } \\
\text { National Committee for the New River (NCNR) file } \\
\text { appeal to the Board of Zoning Appeals (BZA) }\end{array}$ \\
\hline July, 2006 & $\begin{array}{l}\text { Fayetteville Planning Commission approves Bridgeview } \\
\text { Estates plan to develop 1,400 acres along the rim of the } \\
\text { New River Gorge }\end{array}$ \\
\hline September, 2006 & $\begin{array}{l}\text { BZA upholds planning commission's approval, Cal Hite } \\
\text { retires as NPS superintendent }\end{array}$ \\
\hline October, 2006 & PAN and NPCA file second appeal \\
\hline November, 2006 & PAN and NPCA withdraw appeal \\
\hline April, 2007 & Don Striker named new NPS superintendent \\
\hline August, 2007 & $\begin{array}{l}\text { Fayette County Commissioners approve a development } \\
\text { plan for Wild Rock WV a } 744 \text { acre housing development } \\
\text { along Class VI River Runners }\end{array}$ \\
\hline January, 2008 & NPS working on draft for General Management Plan \\
\hline February, 2008 & $\begin{array}{l}\text { President George W. Bush signs economic stimulus } \\
\text { package }\end{array}$ \\
\hline May, 2008 & $\begin{array}{l}\text { Fayette County Planning Commission holds a public } \\
\text { meeting to discuss a possible viewshed ordinance }\end{array}$ \\
\hline May, 2008 & Many Interviews Conducted for Research Study \\
\hline July, 2008 & $\begin{array}{l}\text { LRC closes Fayetteville office and construction on } \\
\text { Roaring River has stopped }\end{array}$ \\
\hline August, 2008 & $\begin{array}{l}\text { NPS plans to purchase } 100 \text { acres from Bridgeview } \\
\text { Estates }\end{array}$ \\
\hline October, 2008 & LRC files for bankruptcy \\
\hline December, 2008 & LRC's land to be sold at auction \\
\hline January, 2009 & President Barack Obama is inaugurated \\
\hline February, 2009 & $\begin{array}{l}\text { President Obama signs another economic stimulus } \\
\text { package }\end{array}$ \\
\hline March, 2009 & $\begin{array}{l}\text { NPS General Management Plan draft is under internal } \\
\text { review }\end{array}$ \\
\hline
\end{tabular}


Statutory Support for Collaborative Land Use Planning

A number of statutory and administrative laws and rules enable NPS to managers to engage communities "in and around" the New River Gorge National River. For instance, the park's enabling legislation (Public Law 95-625) states that "The Secretary of the Interior shall establish and administer the New River Gorge National River...for the purpose of...conserving and interpreting outstanding natural, scenic, and historic values and objects in and around the New River Gorge." This means that NPS is allowed to work with communities "in and around" the park as part of their planning process to ensure that lands surrounding the park boundaries are conserved for their scenic, natural and historic values. For that reason, NPS created an "in and around" map (Figure 1.) detaining those boundaries and views that aide in determining what should be protected "in and around" the New River Gorge National River. 


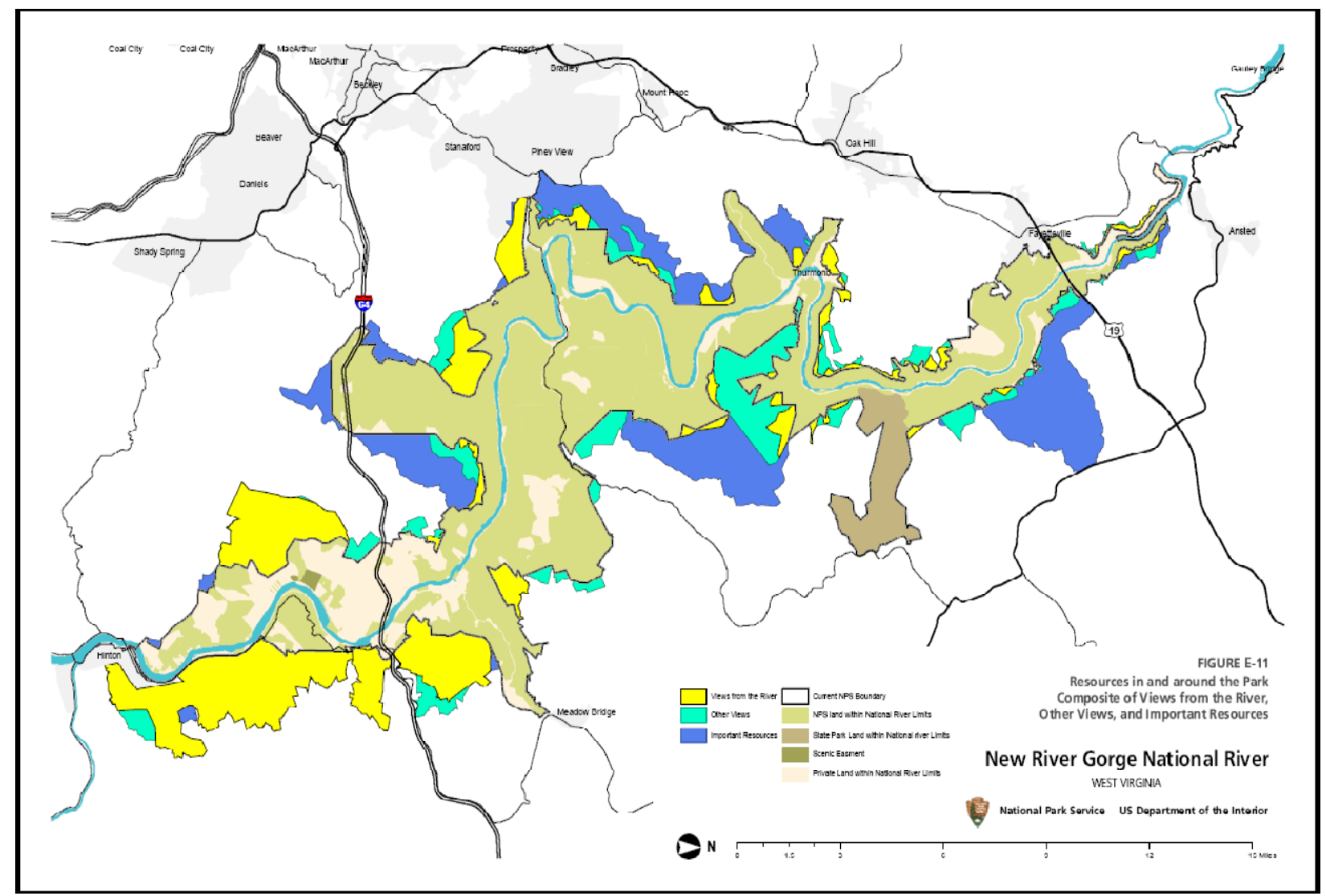

Figure 1. "In and Around" New River Gorge National River

As one NPS employee explained, "the legislation that allows us to do that tells the Park Service to look at lands in and around the new river gorge that merit protection and so we've always taken that to mean that we were not strictly limited to our proclamation boundary, that we could work with communities outside the proclamation boundary to protect nationally significant features or buffer areas that in turn protect these significant features and Fayette County..."

Secondly, a part of the General Management Plan discusses a plan called "alternative four" that deals specifically with gateway communities in an attempt to, as a NPS employee pointed out, "flush out how the park service could work with both the communities that are internal to the boundary but also the communities that are outside the boundary on a variety of different types of projects including conservation and preservation of values." Consequently, NPS is looking for ways to work with 
communities to engage in collaborative land use planning efforts that "are pretty far outside the boundary...but also these little communities that perch on the rim...and of course...the communities that are within the park boundary."

Internal Collaborative Land Use Planning Facilitators and Constraints

Study participants identified a number of organizational factors, internal to NPS that tend to either facilitate or constrain the expansion of collaborative land use planning "in and around" the New River Gorge National River. Table 2 lists the internal factors, both facilitators and constraints, within the Park Service to collaborative land use planning.

Table 2. Internal Factors to the National Park Service Shaping Collaborative Land Use Planning

\begin{tabular}{cc}
\hline Facilitators & Constraints \\
\hline Focus Shift & Financial Capacity \\
Superintendent Orientation & Human Capacity \\
\hline Toward Participatory Planning Models & \\
\hline
\end{tabular}

Internal Facilitators. The Park Service has expanded its focus beyond managing just within the park boundaries to actively engaging outside stakeholders and communities. A NPS employee affirmed, “NPS policy encourages coordination with your neighbors...your stakeholders, your gateway communities..." Stakeholders outside the Park Service boundary are noticing a shift in the Park Service's focus as well. A conservation non-profit manager explained that "you're starting to see this shift from this legacy of, "we are the stewards of this land inside our boundaries' very inward focus to a more broad focus." The county administrator added that there has been that focus shift in other federal agencies particularly in the Forest Service mostly "because the budgets are going down and down and 
down that they're finding that they do have to reach out to people who are around them and acknowledge that these people are part of the park." For example, as stated earlier, a part of the General Management Plan called "alternative four" deals specifically with examining how NPS can better work with gateway communities. So it appears that as budgets continue to decrease, federal agencies, in this case the NPS, will keep on looking for ways to work with stakeholders through collaborative land use planning.

Another factor that tends to facilitate collaborative land use planning is the superintendent's orientation. As illustrated in the timeline, the New River Gorge National River had two different superintendents during the housing development issue; one retired in September 2006, and another became superintendent on April 2007. For that reason, different NPS superintendents tend to have different views about collaborative land use planning and engaging stakeholders. A NPS employee noted an interesting occurrence that the closer a NPS superintendent is to retire the more "aggressive" the positions taken on particular issues. Whereas, the current superintendent that is far from retirement hopes to have a "more meaningful dialogue and actual compromise." Land developers noticed this as well asserting that during LRC's land reclassification issue, the previous superintendent "drew the line in the sand pretty strong" and "tried to drive communities toward his point of view" whereas the current superintendent is "more of a team player." Conversely, a conservation non-profit thought that the "clear lines drawn" by the previous superintendent were "great" but admitted that it "also made it hard to have that dialogue" and another respondent, a county elected official, thinks the current superintendent "will talk the line" and "say... what I want to hear, but I'm not quite so sure." Therefore, it appears that the leadership style of a Park Service superintendent as well as how other stakeholders perceive that superintendent can play an important role in how directly the NPS engages in collaborative land use planning. 
A third internal facilitator of collaborative land use planning is the institution-wide trend toward the NPS adopting more participatory planning models, as expressed most directly in their General Management Plan (GMP) planning process. Wondolleck and Yaffee (2000) describe how resource management agencies are adopting more collaborative planning approaches in response to shared problems and the simple need to move forward. In the case of the New River Gorge, the NPS has sought out stakeholder input by conducting a series of public input meetings during the GMP planning process beginning in January 2006. For example, during the scoping phase of planning, NPS planners asked stakeholders "What Do You Value Most about the Park?" Stakeholders mention several values of the park from the diverse outdoor recreation opportunities, to historic aspects, to simple "peace and solitude". By seeking the public's input during each phase of the planning process, the National Park Service is adopting more participatory models of institutional planning, which tends to contribute to their active engagement in collaborative land use planning initiatives at different scales.

Internal Constraints. Two internal constraints within the NPS were observed through this study 1) Financial Capacity and 2) Human Capacity. Most respondents discussed financial or human constraint in the NPS at some level. The financial capacity became more apparent in the year 2008 as the economic downturn began to really affect budgets of many organizations. Two NPS employees pointed out that "the funding is obviously the biggest constraint" and "the appropriations we get every year are not sufficient to meet our rising costs" indicating that NPS does not have the funding to participate in collaborative land use planning. A land developer observed this as well by declaring, "I think money is another big constraint, because of the fish and wildlife funds that fund a lot of our parks and government agencies is really a fund that's been dropping over the last several years, so the monies aren't there. So it's a real challenge." The other constraint, human capacity means that in addition to not having enough funding for collaborative land use planning projects; NPS does not have adequate 
staffing as well. This was also reflected in the timeline as people were being laid off from jobs as a result of the economic downturn. All NPS staff respondents remarked that either "it's just a lot to do and I would say not that many people" or "it's probably not that people don't want to be involved but it's kind of a lack of personnel." Another NPS employee added,

We have a list that's 3 pages long single spaced of all the agencies and groups that we feel like we need to have regular contact with and we've divided that list down so division chiefs each have some other people have some, we all have some and even doing that we're just scratching the surface of what really needs to be done to do the best job we can for this park and I think that's the biggest thing right there...

It seems as though NPS has a goal to engage stakeholders in collaborative land use planning, however financial and human capacity constraints often limit their ability to engage as many stakeholders as they would like to.

\section{External Collaborative Land Use Planning Facilitators and Constraints}

In addition to internal factors, study participants identified several external factors and constraints to collaborative land use planning (Table 3). These are factors external to the NPS that either facilitate or constrain collaborative land use planning. 
Table 3. External Factors Influencing Collaborative Land Use Planning

\begin{tabular}{cc}
\hline Facilitators & Constraints \\
\hline Converging Interests in Sustainable & Lack of Trust \\
Degional Economic Development & Politics \\
Capitalize on Tourism & Time and Money \\
& Lack of Communication \\
\end{tabular}

External Facilitators. The first facilitator of collaborative land use planning observed were converging interests in sustainable development. In this case, developers are starting to see the need to create sustainable homes and maintain the "aesthetic values" of the area to cater to interest of "green" consumers and perhaps reflecting their own environmental values. One land developer stated that he encourages "small houses" that have the least minimum impact on the land while another land developer explains, "the housing developers here...they understand that their market in this area is probably looking for a, a specific reason. And that those reasons are aligned with keeping the aesthetic values and...the sustainability of the area intact." Other stakeholders encourage sustainable development among land developers. A conservation non profit declared, "we have the chance to do it right if the people want to take the time and take the reigns in a make people do it right." This suggests that there are some efforts among developers to develop more sustainably and preserve the scenic beauty of the gorge.

Another external facilitator is a shared interest in regional economic development. Stakeholders are increasingly working together to expand economic development in the multi-county region instead of just the New River Gorge. Several respondents mentioned the $4 \mathrm{C}$ branding initiative 
which is creating a New River Gorge brand for the 4 counties in the New River Gorge region: Nicholas, Fayette, Raleigh, and Summers. With this initiative, a NPS employee explained, economic development is a "big driver" and the New River Gorge branding effort is much like "when you're watching the Weather Channel they always show what's happening in the Smokies?...It's not necessarily Smoky Mountain National Park but its that whole region? So that's the same thing they're trying to do here with New River Gorge..." Another NPS employee believed NPS is "in there thick" with the 4C branding initiative not only because he believes NPS can play "a key role" but also, he added, "you can't say no to development, right?" From a non-NPS perspective, a conservation non-profit suggested that the branding initiative is important for economic development because "it's more than just Fayette County, it's more than just Raleigh County." Therefore it appears as though the branding initiative is a major step toward the economic development of the New River Gorge area.

Another external facilitator identified by participants reflects regional opportunities to expand tourism development through regional coordination. Participants again mentioned the branding initiative as a way to, a county elected official puts it, "to capitalize on tourism" and the branding initiative can help "get an identity to the area". A conservation non-profit agreed, declaring, "tourism is kind of its natural link, you don't market for someone just come to Fayette County." Furthermore, a county elected official affirmed that with a New River Gorge brand, it can help promote "attractions that are not in Fayette County" so that instead of just visiting Fayette County, they could go to Raleigh County or Summers County to view their attractions. NPS employees see tourism as the "unspoken potential" for economic development mentioned earlier. Moreover, an NPS employee explained that regional coordination can help bring tourists in "from not far away and stay for as long as possible" doing "multi-activities, multi-days." So, similar to regional economic development, a shared interest in 
expanding regional tourism opportunities is another external facilitator to collaborative land use planning.

External Constraints. The external constraints to collaborative land use planning first include the perceived "lack of trust" between others and the Park Service. One land developer maintained that "this is the old us-versus them and government versus big businesses." The developer also included, "so in regards to wanting to work together? Yeah l'd love to work together. But can we trust 'em? I think their agenda and my agenda are two different agendas." A county elected official clarified the perceived lack of trust between people and the Park Service by replying "there's also a big element of folks who resent the National Park Service and...I think many of them would be hard-pressed to tell you why, except that it is the government, which somebody has laid down a claim on this land." Even a NPS employee observed that some people “...was like, you're the feds and we're not, and that's why l'm not going to talk to you." However, NPS noticed the need to establish trust among stakeholders, declaring, "you have to have a solid foundation of those relationships before...you have to have that before you need it. So you can't just walk into a new situation, and think that all of a sudden people are just going to trust you..."Consequently, collaborative land use planning is hindered as a result of stakeholders not being able to trust NPS because they are a government agency, and there is a pervasive notion among many that government agencies are not to be trusted. It will be up to NPS to determine how to build those relationships and gain stakeholders' trust.

A second external constraint is that politics can oftentimes get in the way of collaborative land use planning with stakeholders. This is documented among NPS employees and outside stakeholders. One NPS employee asserted, "sometimes there are some political considerations that limit where we go or what we say or what we do" while another NPS employee points out, "it's just a shame that the federal process puts us in a position where those relationships are damaged and we can't do a thing 
about it and we've done everything we could in that particular instance..." An outfitter also pointed out that politics can constrain collaborative land use planning because it can be hard for someone to see different sides of an issue once they offer support to one position. In the case of the LRC land reclassification issue, he elucidated, "and politics certainly burden it, you know someone gets behind a project like the [county elected official] for example, they generally never change their position regardless" Thus, politics can hinder collaborative land use planning in both the ability of the NPS to build relationships with other stakeholders and a stakeholder's position on particular projects.

Another external constraint is time and money. Similar to the NPS's internal constraints of financial and human capacity, many stakeholders did not feel they have the manpower or the resources to engage in collaborative land use planning. A land developer elaborated:

time and money are going to be two of the biggest...because it takes an awful lot of time, on everybody's part, not only the Park Service do they have their own agenda and their mandate to manage their property which they presently have, but if you ask anybody outside of that as a business concern, I also have from my standpoint I've got a lot of, of, of concerns that I get tied up just making sure that we get to do what we need to do.

A tourism official replied "well there's always the dollars" in regards to funding constraints and that "you have...to be able to acquire some of the dollars to do some of these things." A business owner agreed, declaring, "it's always financial" and that people become worried "about losing potential money." So, collaborative land use planning is often constrained by people not being able to devote time to the process as well as funding not being available to fund the effort.

A fourth external constraint observed is a lack of communication between stakeholders. There are a couple reasons for this lack of communication. The first is that lack of communication can 
eventually lead to litigation if not immediately resolved. A conservation non-profit revealed, "that's what'll happen anytime...you can't get people together and come to some sort of agreement then you're gonna have a lawsuit." For instance, in May 2006 after the Fayette County Planning Commission approved LRC's land reclassification for development, several conservation groups appealed the decision to the Board of Zoning Appeals in what a conservation non-profit called "a perfect example of what happens when we don't come together and have conversations as adults." Another lack of communication factor mentioned by respondents are individual agendas. People, according to a business owner, are worried more about "what's in it for me" than engaging in collaborative land use planning. A county elected official added, "individual agendas will get in the way of this kind of stuff. The one person who has a good reputation, will express great concern over this viewshed discussion, because they have yet to develop the property that they own in the gorge." Lack of communication, whether out of fear of lawsuits or because of individual agendas, can limit collaborative land use planning. Individuals often do not want to work together because of previous litigation as well as being more focused on what is going on within their own organization.

The fifth and final external constraint observed was community resistance to regional coordination. Surrounding communities either do not want to engage in planning with organizations such as the Park Service or do not see a need to engage in planning with communities that are farther away. A community activist noticed that as she lived in the New River Gorge for the past few years people are "very focused on their county" meaning people will say "I'm from Fayette County or Raleigh County" and when it comes to engaging in collaborative land use planning it "is really hard for some folks cause they don't necessarily see why they should care about what's going on in Summers County, it's a place that's an hour away..." NPS employees also detected a "willingness or unwillingness for some of these counties to welcome us." One NPS employee articulated that "now Summers County is 
embracing our partnership efforts, we're still not in as favorable a status with Raleigh County. Fayette County had the most long standing relationship even though its sort of gone up and down through the years with personalities." A NPS employee also suggested that, it is "just simply whether they want to engage with you and whether you feel like there's been an invitation extended." Hence community opposition particularly with surrounding communities are either focused on their own community or are just unwilling to engage in agencies such as NPS.

\section{Ongoing and Planned Collaborative Land Use Planning Initiatives}

Respondents listed a number of ongoing and potential collaborative land use planning initiatives in the New River Gorge region as illustrated in Table 4. These initiatives are projects currently going on in the New River Gorge National River as well as projects that are either in the planning stages or just starting up that have the potential to engage more stakeholders in collaborative land use planning.

Table 4. Collaborative Land Use Planning Initiatives in the New River Gorge National River Region

\begin{tabular}{cr}
\hline Ongoing & Potential \\
\hline $4 C$ & 4 C expansion \\
Transition Team & New River Working Group \\
Summers County Comprehensive Planning & Standardization of Rules and Regulations \\
New River Gorge General Management Plan & Technical Assistance to Communities \\
\end{tabular}

Ongoing Initiatives. The first ongoing initiative is the $4 \mathrm{C}$ branding initiative. As alluded to earlier, 4C is a New River Gorge brand of the four counties considered in the New River Gorge region, Nicholas, Fayette, Raleigh and Summers Counties. Numerous stakeholders mention the $4 \mathrm{C}$ branding initiative. 
The goal of the $4 \mathrm{C}$ is, according to a NPS employee, create a New River Gorge brand much like the Smoky Mountains region in order to bring "new businesses to the area and tourism." As mentioned earlier, NPS is involved in the 4 C initiative because it is, as an employee stated, "really perfect for us because it includes counties in the New River Gorge Region." A conservation non-profit added "4C is just really easy catch region for us because it includes three counties that the park is in plus Nicholas County which has Summersville Dam and Summersville Lake and a lot of other great natural resources." Land developers recognized a need for having the $4 \mathrm{C}$ initiative "in place" because of the fact that "people are moving away from here" and that in order to develop economically, "we've gotta start to change some of those things..." As mentioned earlier, the $4 \mathrm{C}$ branding initiative is what most stakeholders believe is a good ongoing project for collaborative land use planning. It involves a "multicounty" effort among stakeholders with a goal of bringing more business and tourism to the area.

The second ongoing initiative is the Transition Team. The Transition Team is a group of volunteers from several districts in Fayette County who meet and according to a county administrator "...try to get out ahead of the curve, anticipate things that are coming down, revisit the planning process and then recommend ordinance changes." The Park Service is also involved in the Transition Team by holding a "non-voting seat" that is usually filled by the "associate superintendent." The Transition Team works on a variety of projects. For example, a NPS employee affirmed the Transition Team has done "infrastructure improvements" and "beautification efforts" but mostly, the Transition Team "advise[s] the planning commission and planning commission advises the county commission and then it kind of goes from there." The Transition Team is also according to a NPS employee "pretty permanent...it's been meeting for at least...ten years" indicating that there were some collaborative land use planning efforts going on before the development issue came up. 
A third ongoing initiative is the Summers County Comprehensive Plan. As revealed earlier, NPS feels that Summers County is now "embracing our partnership efforts" that they are assisting them in developing that county's first comprehensive plan. NPS has provided Summers County with technical assistance such as expert advice and "GIS services." By working with Summers County on their comprehensive plan, it gives Summers County, a, as stated by a conservation non-profit, "platform to have these discussions." Furthermore, a NPS employee maintained, "since the park's conception in some administrations more and others less worked with surrounding jurisdictions on things like comprehensive plans" meaning that depending on the NPS administration at the time, some would make an effort to engage surrounding communities in collaborative land use planning whereas others would not.

The final ongoing initiative is the New River Gorge General Management Plan (GMP). As seen in the timeline, the NPS is in the process of drafting their GMP for the New River Gorge which will be released to the public in late 2009. NPS sought out the public's input in the GMP process by holding informational public meetings as a way to, according to a NPS employee "help open up the lines of communication" and help communities better "understand the economic impact of having a national park or three national parks in your backyard." From a non-NPS perspective, in this case a business owner, one of the goals of the GMP "was to make all of these towns around here into gateways" specifically "rim to river gateways" by adding "signage." By including stakeholders such as community members and the general public, the GMP is an ongoing collaborative land use planning initiative that not only seeks the public's input but also hopes to educate the public about the benefits of having a national park in their "backyard."

Potential Initiatives. Respondents mentioned a number of potential collaborative land use planning initiatives. The first potential initiative is $4 \mathrm{C}$ expansion. This includes building on what the $4 \mathrm{C}$ 
has already done. A conservation non profit suggested that the next step for $4 \mathrm{C}$ would be to get a "regional board together" so that there is "just little organic sharing of knowledge between the counties and the regions..." An outfitter reinforced that as well by declaring that "we need to keep 4C in the game" and $4 \mathrm{C}$ is in "a pivotal position to provide some leadership" and that it is "that same educational process involve[ing] getting people who don't spend much time together, together." Finally, a NPS employee remarked that $4 \mathrm{C}$ should continue to "be engaged" in collaborative land use planning efforts.

A second potential initiative is the New River Working Group. The New River working group is a group that consists of a small number of groups meeting together and discussing what is currently going on in the New River Gorge Area. An outfitter sees the working group as "a great plan" for getting "various players together to connect." Right now the group consists of, according to a conservation nonprofit "more of the conservation community" but the goal is "to expand it at some point, but we try to get it to a group that we can have a discussion without bogging it completely down." Another goal of the working group is to get the Park Service involved "in kind of a non-public meeting platform to talk about what's going on" because "it's really easy in a public meeting for everyone to just stand up and say...this is what we're doing and everyone comments and some pot shots are thrown and they threaten to get to shoot people and...its fun, but not very effective." Although mentioned only by a couple respondents, the New River Working Group appears to be a potential collaborative land use planning initiative that can continue to develop as more stakeholders become involved.

Another potential collaborative land use planning initiative is organizations working together to share information, technology and create a standardization of rules and regulations for people in the county to follow. This was an initiative confirmed mostly by county administrators. One county administrator explained that "we somehow have to get back to moving the municipalities along the curve at the same time as us" and that that, 
I do think it probably becomes cumbersome for parks service or any developer or an other outside agency to look and they can go online and pull up our code and everything else and 'oh that's what we have to do' and then next thing you know they're in Fayetteville or Oak Hill not understanding the standards and the goals are different so I think the best thing we could do is get more standardization.

Another county administrator elaborated that the Park Service can "join hands with us" in favor of "gathering information" that can help them create more standardization.

A fourth potential initiative is providing technical assistance to surrounding communities. This was alluded to earlier by providing nearby Summers County with GIS services and assistance on their first comprehensive plan. A NPS employee commented that the reason providing technical assistance to surrounding communities is important is, "because most of these little communities don't have the money to have somebody who knows about that on staff, ones that are [un]incorporated don't have a staff..." A county administrator also observed potential in again "join[ing] hands" with the Parks Service "in regard to a lot of the technology that they have, in regard to mapping..." Therefore, it seems that both NPS and county administrators see the potential in working with communities by providing technical assistance to community planning processes.

Finally, the fifth potential initiative for collaborative land use planning in the New River Gorge is organizations working together to create a viewshed ordinance. In May 2008, a public meeting was held to discuss a potential viewshed ordinance for the New River Gorge. The purpose of the meeting was to develop an ordinance in order "to maintain a viewshed's intrinsic value, scenic value and/or economic value through the exclusion, screening and/or buffering of any objectionable structure or land disturbance activity." The meeting, which was attended by several stakeholders, was met with mixed 
reviews. Land developers called the ordinance a "joke" and "huge overkill" while a county elected official described the meeting as "interesting...because we got to see a lot of the selfish interests of some individuals play out..." Conversely, other stakeholders such as a conservation non-profit described the meeting as "productive" and was "happy to have that conversation." A county administrator also felt that "everybody that was there is interested" in seeing an ordinance developed. A NPS employee agreed that the viewshed ordinance is a result of people "thinking future, more then, twenty years where are we going with this thing..." and that initially people were thinking that "growth is good, and now they're beginning to see, oops maybe we need to put more sideboards on." The potential viewshed ordinance initiative is an example that while this planning effort may not receive unanimous support, it can still be an important step in getting stakeholders to engage in collaborative land use planning.

\section{Keys to Successful Collaborative Land Use Planning}

Respondents mentioned several keys to successful collaborative land use planning (Table 5). Of those keys, a "top ten" was created. The keys to successful collaborative land use planning are ideas stakeholders had that could improve collaborative land use planning in the New River Gorge.

Table 5. Keys to Successful Collaborative Land Use Planning

\begin{tabular}{llll}
\hline$\bullet$ & Building Relationships & $\bullet$ & Leadership \\
\hline$\bullet$ & Communication & $\bullet$ & Education \\
$\bullet$ & Community Engagement & $\bullet$ & Sustainable Economic Development \\
$\bullet$ & Good Neighbor & $\bullet$ & Third Party Facilitation \\
$\bullet$ & Involve Civic Organizations & $\bullet$ & Further Park Engagement \\
\hline
\end{tabular}


The first key to successful collaborative land use planning is building relationships with stakeholder groups. Building relationships is especially important after communities were divided during the peak of the housing development issue in the New River Gorge. A conservation non-profit affirmed "you really gotta find those folks who can build those bridges between a lot of different stakeholders" and that everyone needs "to come together if we're gonna have successful regional planning...we need the developers in the same room with the conservationalists...and be able to have a conversation." A land developer thought that relationships are "already happening" in the area and pointed to an example of a "week-long workshop on balance in nature and gateway communities and economic development" that was attended by "Park Service personnel, CVB directors, land developers, and managers" that was a good way for the park and stakeholders to "work together." Lastly, a NPS employee added, “we can't be all things to all people, but they can understand the piece that we are in every puzzle that'll go along ways to helping relationships." For that reason, continuing to build relationships among the different stakeholders is a key to successful collaborative land use planning.

The second key to successful collaborative land use planning is communication. Communication concurs with the research of Selin and Schuett (2002) as a key to successful collaborative land use planning. In the case of the New River Gorge, communication is about, as a city administrator put it, "letting each other know...what our priorities are...areas there that we want to grow together...to make each other stronger." A county administrator saw communication as "stakeholder groups...sitting down at a table together...over the course of a day or several days and exchange information." The county administrator added that there are people in particular, the assessor's office who has a "different take on EVERYTHING than even the commissioners let alone the Park Service, and I'm sure there are people in the Parks Service that we never interact with that it would be helpful for use to finally hear what their role is." Lastly, a NPS employee suggested that communication is about getting "everybody rowing in 
the same direction" but warns that it can be hard because "they'd rather argue than work on stuff." Therefore, whether explaining priorities, exchanging information or just trying to get people moving "in the same direction," despite it being difficult at times, can be a successful key to collaborative land use planning.

The third key to successful collaborative land use planning is community engagement. This involves getting community members involved in collaborative land use planning efforts. A city elected official encouraged "people with ideas or concerns...to attend planning and zoning city council meetings." NPS employees added that community engagement is more educational and "these communities understand why the National Parks are important to the economy of the local community" and that "preservation of the park and its resources is why tourists come and they won't come if that stuff's not protected." Another NPS employee noticed that communities are "very interested in more coordination" and are "definitely pushing for coordinated projects" because of "a lot more fairly recent successes." For that reason, as communities become better educated about the need to preserve the park, they will push for more collaborative land use planning efforts.

A fourth key to successful collaborative land use planning is being a good neighbor to surrounding communities. A city administrator referred to a good neighbor as knowing "what's beneficial to one hopefully will be beneficial to the other" and referred to an example of a new skateboard park built that can be beneficial to all surrounding communities because "they're going to come to Fayette County, they're going to come through Nicholas County, they may go through Gauley Bridge and Ansted." A NPS employee rejoined, stating that communities should embrace the NPS "as their neighbor and wanting to be proud of the fact that they have this National Park Service Unit right in their backyard and they would come to us and say Give us the information that we need so we can adequately protect the areas." Hence being a good neighbor is about not only knowing what is 
"beneficial" to surrounding areas, but also wanting to "adequately protect" what is in those surrounding areas.

A fifth key to successful collaborative land use planning is getting civic organizations such as Lion's Club, and Rotary involved in collaborative land use planning efforts. A city administrator discussed,

Civic organizations are the ones...already giving to the community and giving back to the community and giving back to the community and are already involved with your boards, or made up of individuals that already give back so you look at those people that are giving and volunteering in the community, they're the ones that are gonna sign up and say, yeah, l'll serve on that board when asked

NPS has already begun to engage civic organizations, the current superintendent, joined the Rotary in Beckley to "build relationships" so it appears NPS is starting to engage civic organizations, which may prove to be a key stakeholder in collaborative land use planning efforts.

A sixth key to successful collaborative land use planning is leadership. An outfitter stated that "you gotta have some leadership that's real and you gotta have a vision for the future and you gotta have some leadership to make it happen and cut through the bulls-t." A business owner also pointed to leadership and that "you've gotta get personalities that are small egos that can communicate between multiple groups. An NPS employee also felt leadership plays an important role but cautioned that "newcomers" can "just get rejected by what they perceive as probably is legitimately the founding fathers, the old-boy network." So even though leadership can be an important key to successful collaborative land use planning "newcomers...trying to get a role in leadership" could meet some 
resistance among stakeholders, who may not want their leadership because that person is not part of the "old-boy network."

The seventh key to successful collaborative land use planning is education. Education is simply getting out and educating the public, similar to the community engagement aspect mentioned earlier. An outfitter talked about the importance of having "a lot of education going on" and that "you really gotta talk to the kids." The outfitter goes on to discuss an "environmental film festival" they did for "high school kids" that "had a huge impact, and those are the ingredients, but you gotta have some element in the public that's tipping things toward stewardship." A tourism official also clarified that "education is probably a real key" in particular, people need to be educated about "how you can balance...nature and commerce." A NPS employee believed that the NPS itself needs to be educated and "understand the communities and what their concerns and issues are and find ways to help them." The employee added, "we try by going out and being on these boards and serving on these committees and doing these listening tours...and even the public meetings..." Consequently there needs to be education at all levels from child, to other stakeholder groups, to NPS itself learning ways to preserve their park and engage communities.

An eighth key to successful collaborative land use planning is sustainable economic development. Similar to the external facilitator that land developers are seeing the need to create sustainable homes mentioned earlier, but communities are creating more sustainable economic development to preserve the natural beauty of the area. A county elected official elucidated that nearby towns "are saying why is Fayetteville the shining star in our county, and what can we do to be more, more like that." Also, he asserted that people want to preserve their "quality of life" and "economic interest" and that those two "are gonna lead to cooperation in the future." A NPS employee believed sustainable economic development could be a key to successful collaborative land use planning 
as well, that "people are beginning to understand that there's value to having a national park and maybe you need to protect the park."

The ninth key to successful collaborative land use planning is third party facilitation. This was also alluded to earlier during the leadership section. Third party facilitation involves someone else who does not have a personal stake in the issues to bring stakeholders together and come to an agreement. A business owner commented that "you've gotta get personalities that are small egos that can communicate between groups." The business owner also cautioned that "I don't know if there's someone around here that can do that, anytime you bring in outsiders to do that, once again you're putting walls up." However, third party facilitation appeared to work well at the viewshed ordinance as several stakeholders mentioned that the facilitator was "fantastic" and "did a good job" at "[drawing] out all stakeholders' concerns." Even though some might feel third party facilitation might "put up walls", others see it as a beneficial key to successful collaborative land use planning.

Lastly, the tenth key to successful collaborative land use planning is further park engagement. This includes further steps the Park Service can take to better engage stakeholders. One way the city administrator thought the Park Service can better engage stakeholders is by coming "to council meetings, schedule to be on the agenda, and say we'd like to do a presentation or maybe just do a presentation to the community as a whole. That would be ideal, and just informing us of what their plans are." A conservation non-profit would also "like to get the park superintendent once a month...to come into town have lunch at [local restaurant] open invitation, anyone wants to come in and say hey? Come on in." But, the conservation non-profit admitted that "once a month is a little much for him." An NPS employee understood the need for further park engagement and suggested that "a big issue in the General Management Plan was to suggest that the Park Service here at New River Gorge could be doing a lot more" as far as further engaging the community because, the NPS employee added, "we really 
have no choice but to work with these communities or providing facilities, on providing signage, on providing protection for key resources and to me it's the core part of the park's mission." It appears that the Park Service is aware of the need to further engage stakeholders "in and around" the Park Service boundary are starting to take measures to do so by again "being on boards,...serving on committees and doing...listening tours." 
Chapter V

\section{Summary and Conclusions}

\section{Summary}

The findings from Chapter Four suggest that NPS is increasingly aware of the need to participate in collaborative land use planning among stakeholders. NPS is able to use the "in and around" clause in the New River Gorge National River enabling legislation as a means to work with surrounding communities. So far, NPS has participated in numerous communities as well as area Rotary Clubs, speaking tours, and working groups to try to inform the public that the park is available to them and engage in collaborative land use planning efforts. Another effort NPS is making toward more collaborative land use planning is through their General Management Plan for the New River Gorge National River. NPS offered public meetings during the GMP process to obtain the public's input as well as establish a greater need to engage communities "in and around" the New River Gorge whenever the GMP becomes available for public view.

Community members are overall willing to participate in collaborative land use planning as well. As one NPS employee noticed earlier, communities are "definitely pushing for coordinated projects" because of "a lot of more fairly recent successes." Because of those recent successes, community members want to be "more like" those successes and work together to preserve their community's overall quality of life.

As indicated on the case study timeline (Table 1.) the NPS at the New River Gorge saw a change in park superintendents. The previous superintendent retired and a few months later, the current superintendent takes office. Therefore the personality of two different superintendents can impact how the park service engages in collaborative land use planning. If one superintendent is inclined to draw 
"the line in the sand pretty strong" whereas another is considered more of a "team player" than it could affect efforts to participate in collaborative land use planning. Community members might be intimidated by a former superintendent who was known by others to be "aggressive" in their positions. It can also be difficult for a new superintendent to come in and gain the communities' trust due to community members being accustomed to the previous superintendent. It will be up NPS to build those relationships with stakeholders and establish trust between stakeholders and NPS.

Regional culture can influence a community's willingness to participate in collaborative land use planning. People who are "focused on their county" oftentimes are unwilling to engage in collaborative land use planning efforts because they do not see the need to work with communities who are located an hour away from them. It can also be difficult if communities do not extend an invitation to NPS to engage in collaborative land use planning initiatives. Community members need to be educated on the importance of working with adjacent communities in order to preserve their community and quality of life.

Collaborative land use planning is constrained by lack of internal capacity both financially and humanly. The financial capacity simply states that because the Park Service's appropriations continue to decline, they are unable to fund further collaborative land use planning efforts. Along with financial capacity there is human capacity in which there are a lot of individuals NPS wants to engage in collaborative land use planning but there is no one available to engage. The NPS at the New River Gorge is understaffed and each employee has multiple responsibilities so again collaborative land use planning becomes difficult. NPS needs additional funding to hire a person who can specialize in working with communities "in and around" the park and can better engage stakeholders. 
Finally, economic scarcity appears to contribute to expanded coordination and resource-sharing. The case study timeline (Table 1.) again illustrated the initial rise of all of these housing developments and, in 2008 how the economic downturn impacted these developments, so much so that the major development company LRC closed their offices and a few months later all 4,300 of their proposed land is sold at auction. Another land developer, BridgeView Estates plans to sell 100 acres of their land to NPS alon with "over 500 more acres that [they] hope to acquire from BridgeView in the long-term." Because of the sudden economic downturn as well as organizations' declining budgets, more and more organizations are beginning to work together and work with the Park Service in preserving land for future generations. Some may even argue that in the case of the New River Gorge National River, the economic downturn might have saved the area from all the potential developments, bought time for NPS to be able to purchase the land, and allowed stakeholders who at one point may have been at odds with one another to work together and reach some sort of collaborative agreement for the gorge.

\section{Scientific Contributions to the Literature}

The findings in Chapter Four supported most previous literature regarding collaborative land use planning. In addition to NPS becoming aware of the need to participate in collaborative land use planning, respondents noticed a change in the Park Service focus from a more inward focus to a more outward, community focus. This focus shift can also be as a result of a societal response to changing conditions where information is more widely distributed to networked societies (Innes and Booher, 1999).

The internal and external facilitating factors described by respondents differed from those stated in the literature review. This is because the facilitating factors observed by respondents such as superintendent orientation and converging interests in sustainable development are more narrowly 
defined than in previous literature. The facilitating factors willingness to try new approaches and focusing on a problem as a whole are more broadly defined factors (Wondolleck and Yaffee, 2000). The internal and external constraints most correlated with the previous literature of Selin and Chavez (1995) and Wondolleck and Yaffee (2000) that lack of resources such as time money, and personnel as well as politics can limit collaborative land use planning. However, community resistance constraint is not mentioned in any previous literature. This suggests that community resistance is a fairly new constraint that perhaps only pertains to southern West Virginia communities.

Most of the keys to successful collaborative land use planning confirmed by respondents correlated with previous literature. Building relationships, communication, third party facilitation, and further park engagement are all measures both respondents and previous literature mentioned are keys to successful collaborative land use planning (Selin and Schuett, 2002; Frame, Gunton, and Day, 2004). This indicates that keys to success such as communication and relationship building are items that can continuously be improved upon.

\section{Toward a Collaborative Land Use Planning Framework}

From the literature review data and data collected as part of this study, we can begin to develop a framework for understanding the conditions that contribute to the efficacy of collaborative land use planning (Figure 2.). This framework can be potentially seen as an "onion" illustrating numerous layers surrounding the efficacy of collaborative land use planning located at the core. By working through or "peeling back" these different factors we can begin to understand these contextual factors that 
contribute to successful collaborative land use planning.

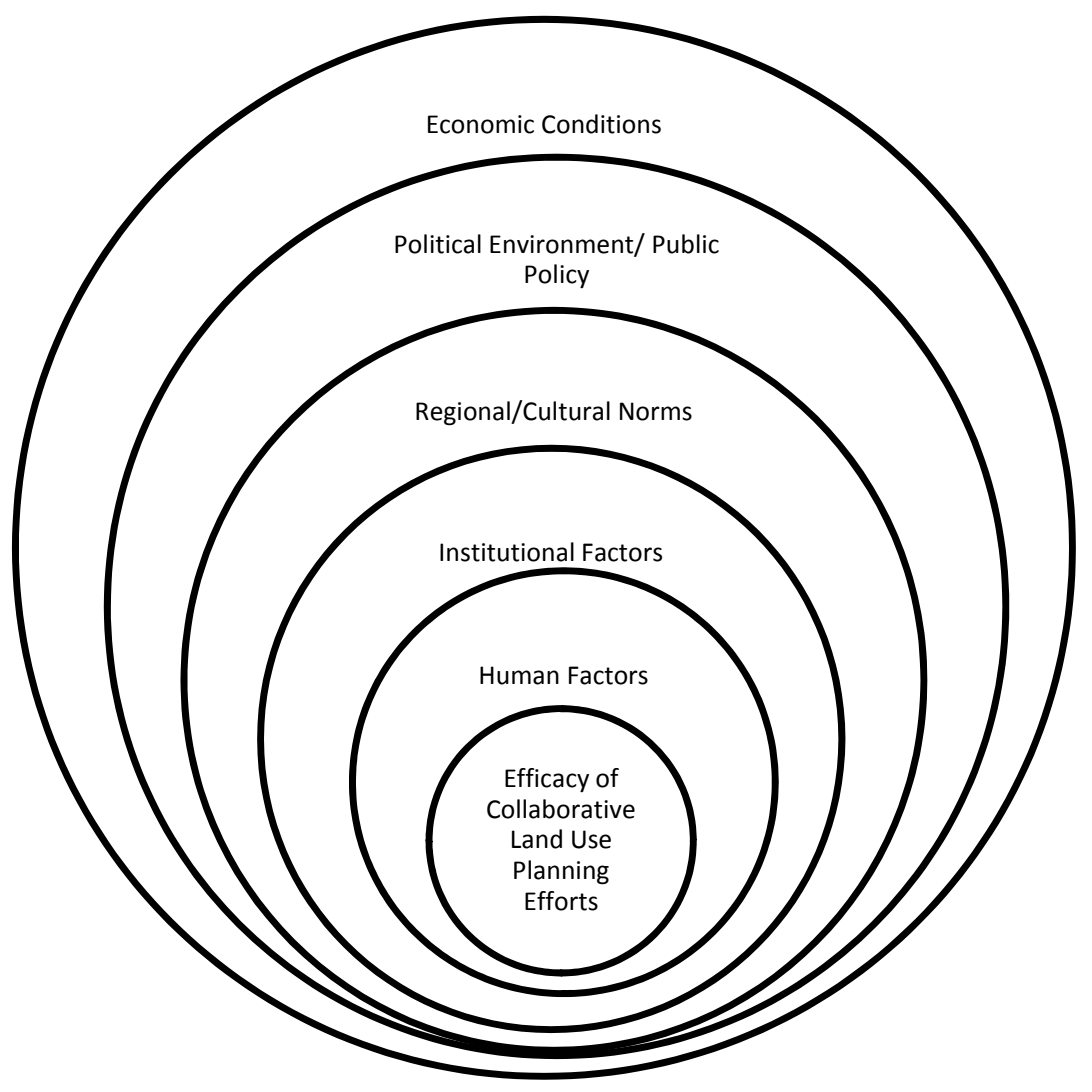

Figure 2. Contextual Factors Influencing Efficacy of Collaborative Land Use Planning Efforts

The human factor layer includes psychological factors such as the personalities of different superintendents, and the level of trust stakeholders have with the Park Service. The next layer, institutional factors deal with factors within an organization, such as administrative rules and strategic plans. The regional/cultural norms include the perceived norms of that community. In this case, community resistance is an example, where communities are county oriented. The next layer is the political environment/public policy. This refers to the political factors such as "red tape" and the limits to what federal agencies such as NPS can say or do. The final and outermost layer is economic conditions. Economic conditions such as declining administrative budgets and the current housing crisis can also be a factor in collaborative land use planning efforts. Again, this model illustrates the several 
layers that can limit collaborative land use planning efforts. Furthermore the framework can be used by other Park Service units to show what needs to be done in order to achieve effective collaborative land use planning.

\section{Suggestions for Future Research}

Because it was discovered during this study that economic conditions play a role in efforts to engage in collaborative land use planning it would be interesting to explore how economic conditions impact collaborative land use planning. In this particular study, we learned that stakeholders were beginning to engage in collaborative land use planning due to declining administrative budgets and that it was important to work together to help preserve the community's resources. Also, as illustrated in the case study timeline (Table 1.) the economic downturn affected the land developers as well. LRC closed their Fayetteville offices and their land was auctioned, while BridgeView is negotiating with NPS to sell 100 acres to NPS in hopes of selling more land to them in the future. For that reason, it would be fascinating to investigate the economy's role in collaborative land use planning efforts not just in the New River Gorge National River but in other Park Service Units dealing with development issues.

Another idea for future research would be to expand the methodology to adjacent counties in the New River Gorge. This study's focus was primarily in Fayetteville, West Virginia with a majority of interview participants located in Fayetteville as well. It would be interesting to talk to the stakeholders in the other three counties in the four county New River Gorge region, Raleigh, Summers, and Nicholas to see what efforts toward collaborative land use planning are taking place particularly with NPS. As stated earlier, one external constraint was community resistance in which communities appear to be focused only on what is going on in their county. Therefore it would be worthy to not what if any efforts have been made to engage in collaborative land use planning with NPS. 


\section{Suggestions for Professional Practice}

NPS should continue to take a more hands-on approach in engaging stakeholders, not only in the New River Gorge National River, but in other NPS units as well. Because the NPS at New River Gorge is unique in having the language of "conserving and interpreting outstanding natural, scenic, and historic values and objects in and around the New River Gorge" NPS is able to actively work with surrounding communities in collaborative land use planning efforts. It is important that other NPS units work to include an "in and around" amendment to their legislation in order to better engage in collaborative land use planning with stakeholders.

Another way NPS can take a hands-on approach with stakeholders is by creating a more visible presence in the community. One way this can be achieved is to first give regular presentations at city and county planning meetings to keep the community informed as to what is going on within the Park Service and inform the public of any upcoming regulations that they should be aware of. The NPS at the New River Gorge is involved in numerous committees and organizations in the New River Gorge region. For example, NPS holds a non-voting seat on Fayette County's Transition Team so they can provide input and assistance to the team without being responsible for making decisions. NPS at the New River Gorge also provides technical assistance to surrounding communities such as providing nearby Summers County GIS services that the county would not have been able to obtain otherwise. Furthermore, NPS should sponsor informal lunch sessions in the community. By having an NPS superintendent either once a month or otherwise, eat lunch at a local restaurant can not only give NPS a more visible presence in the community, but it also makes NPS more approachable and stakeholders have a chance to address their questions and concerns in an informal setting. 
A final suggestion for NPS management practices is to continuing to engage and educate the public on preservation issues. Sponsoring informational booths and tables at community fairs and festivals will again give the public a chance to approach NPS in an informal setting but gives the community a chance to read about what NPS can do for them as well as the importance of preservation. Also, one of the suggested keys to successful collaborative land use planning was talking to the kids and educating them about preservation. The respondent mentioned that they did an environmental film festival and it had a huge impact. Another way to engage youth would be to use technology and social networking sites like Myspace and Facebook. NPS could create a page that features information about their particular park as well as tips for preservation and how to become better engaged in the community. Finally, NPS should work with stakeholders in creating a viewshed ordinance to protect areas "in and around" the park. By creating a viewshed ordinance early on, the viewshed from pivotal areas of the park will be protected so that development can happen, but away from areas that could damage the parks viewshed. Consequently by taking a more hands-on approach, and engaging and educating stakeholders, NPS can be a bigger part in their community and open the door for more collaborative land use planning efforts both in the New River Gorge National River and beyond. 


\section{References}

Allan, C., and Curtis, A. (2003). Learning to Implement Adaptive Management. Natural Resource Management, 6(1) 25-30.

Carruthers, J.I, and Vias, A.C. (2005). Urban, Suburban, and Exurban Sprawl in the Rocky Mountain West: Evidence from Regional Adjustment Models. Journal of Regional Science, 45(1) 21-48.

Coughlin, C.W., Hoben, M.L., Manskopf, D.W., and Quesada, S.W. (1999). A Systematic Assessment of Collaborative Resource Management Partnerships. Unpublished master's project, University of Michigan--Ann Arbor.

Davis, J.S., and Nelson, A.C. (1994). The New 'Burbs: The Exurbs and their implications for Planning Policy. Journal of the American Planning Association, 60(1) 45-59.

Decker, D.J., Brown, T.L, and Siemer, W.F. (2001). Human Dimensions of Wildlife Management in North America. Bethesda, MD: The Wildlife Society.

Eagn, T. (1994, October 11). Oregon Thrives As It Protect Owls. The New York Times, p. A1.

Fisher, R., Ury, W., and Patton, B. (1991). Getting to Yes: Negotiating Agreement without Giving In (2 ${ }^{\text {nd }}$ ed.). New York: Houghton Mifflin Company.

Flora, J.L, Sharp, J, Flora, C. and Newlon, B. (1997). Entrepreneurial Social Infrastructure and Locally Initiated Economic Development in the Nonmetropolitan United States. The Sociological Quarterly, 38(4) 623-645.

Frame, T.M., Gunton, T., Day, J.C. (2004). The role of collaboration in environmental management: an evaluation of land and resource planning in British Columbia. Journal of Environmental Planning and Management, 47(1) 59-82.

Glorioso, R.S. and Moss, L.A.G. (2007). Amenity Migration to Mountain Regions: Current Knowledge and Strategic Construct for Sustainable Management. Social Change, 37(1) 137-161. 
Granovetter, M.S. (1985). Economic Action, Social Structure and Embeddedness. American Journal of Sociology, 91, 481-510

Gray, B. (1985). Conditions Facilitating Interorganizational Collaboration. Human Relations, 38(10), 911936.

Gray, B. (1989). Collaborating: Finding Common Ground for Multiparty Problems, San Francisco: JosseyBass.

Grumbine, R.E. (1994). What is Ecosystem Management? Conservation Biology, 8, 1-12.

Hansen, A.J, Rasker, R., Maxwell, B., Rotella, J.J., Johnson, J.D., Parmenter, A.W., et al. (2002). Ecological Causes and Consequences of Demographic Change in the New West. BioScience, 52(2) 151-162. Hayes, S. (1988). What's Wrong with Mediation? Sylvanian, Feb-Mar 2.

Howe, J., McMahon, E., and L. Propst (1997). Balancing Nature and Commerce in Gateway Communities. Washington, D.C.: Island Press.

Innes, J.E. and Booher, D.E. (1999). Consensus Building and Complex Adaptive Systems: A Framework for Evaluating Collaborative Planning. Journal of the American Planning Association, 65(4) 412-423.

Koontz, T.M. (2003). The farmer, the planner, and the local citizen in the dell: how collaborative groups plan for farmland preservation. Landscape and Urban Planning, 66(1) 19-34.

Krippendorff, K. (2004). Content Analysis: An Introduction to its Methodology (2 ${ }^{\text {nd }}$ ed.). Thousand Oaks, CA: Sage Publications.

National Parks and Recreation Act of 1978. Public Law 95-625. 10 Nov. 1978.

National Parks Service (2008). www.nps.gov.

Patton, M.Q. (2002). Qualitative Research and Evaluation Methods ( $3^{\text {rd }}$ ed.). Thousand Oaks, CA: Sage Publications. 
Putnam, R.D. (1993). The Prosperous Community: Social Capital and Public Life. American Prospect, 13, $35-42$

Riesbsame, W.E., Gosnell, H., and Theobald, D.M. (1996). Land Use and Landscape Change in the Colorado Mountains I: A Case Study of the East River Valley. Mountain Research and Development, 16(4) 395-405.

Rudzitis, G. (1999). Amenities Increasingly Draw People to the Rural West. Rural Development Perspectives, 14(2) 9-13.

Schatz, G., McAvoy, L.H., and Lime, D.W. (1991). Cooperation in Resource Management: A Model Planning Process for Promoting Partnerships between Resource Managers and Private Service Providers. Journal of Park and Recreation Administration, 9(4), 42-58.

Schuett, M.A., and Selin, S.W. (2002). Profiling Collaborative Natural Resource Initiatives and Active Participants. Northern Journal of Applied Forestry, 19(4) 155-160.

Schusler, T.M., Decker, D.J., and Pfeffer, M.J. (2003). Social Learning for Collaborative Natural Resource Management. Society and Natural Resources, 16(4) 309-326.

Selin, S. and Chavez, D. (1995). Developing an Evolutionary Tourism Partnership Model. Annals of Tourism Research, 22(4) 844-856.

Selin, S.W., Pierskalla, C., Smaldone, D., and Robinson, K. (2007). Social Learning and Building Trust trhough a Participatory Design for Natural Resource Planning. Journal of Forestry, 105(8) 421425.

Snepenger, D., Johnson, D.J., and Rasker, R. (1995). Travel-Stimulated Entrepreneurial Migration. Journal of Travel Research, 34(1), 40-44.

Stewart, S.I. (2000). Amenity Migration. Retreived July 13, 2008 from: http://www.prr.msu.edu/trends2000/pdf/stewart.pdf. 
Theobald, D.M., Gosnell, H., and Riesbsame, W.E. (1996). Land Use and Landscape Change in the Colorado Mountains II: A Case Study of the East River Valley. Mountain Research and Development, 16(4) 407-418.

Waddock, S.A. and Bannister, B.D. (1991). Correlates of Effectiveness and Partner Satisfaction in Social Partnerships. Journal of Organizational Change Management, 4, 74-89.

Wondolleck, J.M, and Yaffee, S.L. (2000). Making Collaboration Work: Lessons from Innovation in Natural Resource Management. Washington, D.C.: Island Press.

Yin, R.K. (2003). Case Study Research: Design and Methods (3 $3^{\text {rd }}$ ed.). Thousand Oaks, CA: Sage Publications. 


\section{Appendices}

\section{Appendix A}

Positions of Interview Participants

1. County Administrator

2. Land Developer

3. County Elected Official

4. Tourism Official

5. Outfitter

6. County Administrator

7. Conservation Non-Profit

8. NPS Employee

9. NPS Employee

10. Land Developer

11. City Elected Official

12. Land Developer

13. NPS Employee

14. Tourism Official

15. City Administrator

16. NPS Employee

17. Business Owner 


\section{Appendix B}

\section{Survey Questionnaire}

A diversity of internal and external trends have coalesced to encourage resource management agencies to adopt more regional and coordinated approaches to environmental planning to protect natural, cultural, and recreational resources. For example, the rapid population growth of gateway communities adjacent to public forests and parks have necessitated a more regional approach to land use planning. Resource planners, community leaders, and the development community are considering thoughtful strategies to coordinate planning for the public good and to promote sustainable community development.

To provide support for these efforts, we are planning a case study research project to examine how the National Parks Service has engaged in coordinated planning with the county, city, and development community in the New River Gorge National River region over the past six years as well as to identify realistic opportunities for coordinated planning efforts in the future. We plan to interview key stakeholders as well as to collect secondary data from sources like newspaper articles, technical reports, and minutes from meetings, to name a few.

To help us refine our study plan, we are interviewing some of the key stakeholders. Here are some questions we have today to help develop a deeper understanding of these planning efforts.

0 [for government agencies only]. What statutory/administrative support is there within [your organization] to engage in regional planning efforts outside [your organization's] jurisdictional boundaries?

1. In the case of the New River Gorge National River, can you describe the factors that might encourage [your organization] to engage in more regional, coordinated planning in the future?

2. Also, in the case of the NRGNR, can you describe any factors that might constrain or limit [your organization's] participation in regional, coordinated planning?

3. Over the past six years, describe some of the specific initiatives/projects where [your organization] has engaged in regional, coordinated planning in the NRGNR region.

4. What is the potential for expanding the scope of regional, coordinated planning efforts in the NRGNR region? Any specific ideas?

5. What might be some keys to successfully expanding the scope of regional, coordinated planning efforts in the NRGNR region?

6. Conversely, what might be some potential constraints to successfully expanding the scope of regional, coordinated planning efforts in the NRGNR region?

7. Whom else should we speak to in conducting this research study? 